\title{
Long-term thermal stability of fatty acid anion-based ionic liquids
}

\author{
B. Ramajo ${ }^{a}$, D. Blanco ${ }^{b^{*}}$, N. Rivera ${ }^{c}$, J.L. Viesca ${ }^{\text {b,d }}$ \\ R. González ${ }^{\mathrm{c}, \mathrm{d}}$, A. Hernández Battez ${ }^{\mathrm{b}, \mathrm{d}}$ \\ ${ }^{a}$ Department of Organic and Inorganic Chemistry, University of Oviedo, Asturias, Spain \\ ${ }^{\mathrm{b}}$ Department of Construction and Manufacturing Engineering, University of Oviedo, Asturias, Spain \\ ${ }^{\mathrm{c}}$ Department of Marine Science and Technology, University of Oviedo, Asturias, Spain \\ ${ }^{\mathrm{d}}$ Department of Design and Engineering, Bournemouth University, Poole, BH12 5BB, UK \\ ${ }^{(*)}$ Email: blancoadavid@uniovi.es
}

\begin{abstract}
Isothermal and dynamic methodologies were used to study the thermal degradation of 8 novel fatty acid anion-based ionic liquids (FAILs): methyltrioctylammonium hexanoate $\left[\mathrm{N}_{8,8,8,1}\right]\left[\mathrm{C}_{6: 0}\right]$, methyltrioctylammonium octanoate $\left[\mathrm{N}_{8,8,8,1}\right]\left[\mathrm{C}_{8: 0}\right]$, tetrahexylammonium octanoate $\left[\mathrm{N}_{6,6,6,6}\right]\left[\mathrm{C}_{8: 0}\right]$, methyltrioctylammonium laurate $\left[\mathrm{N}_{8,8,8,1}\right]\left[\mathrm{C}_{12: 0}\right]$, methyltrioctylammonium palmitate $\left[\mathrm{N}_{8,8,8,1}\right]\left[\mathrm{C}_{16: 0}\right]$, tetrahexylammonium palmitate $\left[\mathrm{N}_{6,6,6,6}\right]\left[\mathrm{C}_{16: 0}\right]$, methyltrioctylammonium stearate $\left[\mathrm{N}_{8,8,8,1}\right]\left[\mathrm{C}_{18: 0}\right]$ and methyltrioctylammonium oleate $\left[\mathrm{N}_{8,8,8,1}\right]\left[\mathrm{C}_{18: 1}\right]$.

The thermal stability of these FAILs is controlled by both the cation and anion and most samples have an onset decomposition temperature ( $\mathrm{T}_{\text {onset }}$ ) below $200{ }^{\circ} \mathrm{C}$. All the FAILs exhibited lower thermal stability under a nitrogen atmosphere than commercially available ILs tested previously in lubrication studies, particularly when compared to those containing the $\left[\mathrm{NTf}_{2}\right]^{-}$anion. The $\left[\mathrm{N}_{8,8,8,1}\right]\left[\mathrm{C}_{6: 0}\right]$ and $\left[\mathrm{N}_{8,8,8,1}\right]\left[\mathrm{C}_{8: 0}\right]$ showed the highest long-term thermal stability, probably related to their stronger anion-cation electrostatic interaction. This led to a multi-step thermal decomposition mechanism observed in the DTG results. Finally, isoconversional modelling for the $\left[\mathrm{N}_{8,8,8,1}\right]\left[\mathrm{C}_{12: 0}\right]$ agrees with isothermal results.
\end{abstract}

Keywords: fatty acid ionic liquids; thermogravimetric analysis; isothermal thermogravimetry; isoconversional method; model-free kinetics.

\section{Introduction}

A salt in the liquid state is usually called an ionic liquid (IL), ethylammonium nitrate $\left[\left(\mathrm{C}_{2} \mathrm{H}_{5}\right) \mathrm{NH}_{3}\right]\left[\mathrm{NO}_{3}\right]$ being the first IL reported at the beginning of the last century [1]. More specifically, the term IL used to be restricted to salts whose melting point is below $100^{\circ} \mathrm{C}$. While ordinary liquids are predominantly composed of electrically neutral molecules, ILs are compounds largely made up of ion pairs: bulky organic and asymmetric cations combined with a variety of small inorganic or organic anions $[2,3]$ and this characteristic grants them very interesting properties, such as: extremely low volatility, large liquid ranges and low melting temperature, among others. Furthermore, this variety of physicochemical and thermodynamic properties depends on their cation-anion combinations, which means that they are appropriate for a wide range of applications, due to the large number of cation-anion combinations that are available [4-15].

The idea of employing ILs in lubrication was studied for the first time in 2001 [16] and subsequent research has continued to show promising results $[5,17-20]$. The most common ILs used in the early research were based on the $\left[\mathrm{PF}_{6}\right]^{-}$and $\left[\mathrm{BF}_{4}\right]^{-}$anions [21-23]; but corrosion issues were detected [24-28] and more stable 
fluorine-based ILs containing $[\mathrm{FAP}]^{-}$and $\left[\mathrm{NTf}_{2}\right]^{-}$anions with excellent tribological properties started to be studied in order to avoid the mentioned corrosion problems [28-45]. On the other hand, new families of ILs have been synthesized recently, with the objective of simultaneously achieving low toxicity and high biodegradability [46-52]. A metathesis reaction for the obtention of ionic liquids from fatty acids (fatty acid ionic liquids or FAILs) was firstly reported in 2013 [53]. Then, these FAILs began to be used increasingly in lubrication studies [54-70], which reported that their thermal behaviour was poorer than that of the “conventional" (or commercially available) ionic liquids.

Thermal stability is an important property when considering the application of ILs in lubrication. Although a lot of research into the thermal degradation of ILs has been reported [71-94], their stability has normally been overestimated due to the use of heating rates above $10 \mathrm{~K} \cdot \mathrm{min}^{-1}$. Considering the importance of longterm thermal stability in industrial applications, it is essential to obtain reliable data to evaluate the feasibility of employing a specific IL in each application [95-101]. The search for models capable of predicting long-term stability from the typical dynamic thermogravimetric measurements is more efficient (less time-consuming) and allows the lifetimes of ILs to be used in industrial applications to be estimated $[71,95,102-105]$.

In this work, three isoconversional methods are proposed in order to obtain kinetic parameters without any assumption regarding the reaction mechanism. This methodology was applied to determine the long-term stability of 8 fatty acid anion-based ionic liquids (FAILs): methyltrioctylammonium hexanoate $\left[\mathrm{N}_{8,8,8,1}\right]\left[\mathrm{C}_{6: 0}\right]$, methyltrioctylammonium octanoate $\left[\mathrm{N}_{8,8,8,1}\right]\left[\mathrm{C}_{8: 0}\right]$, tetrahexylammonium octanoate $\left[\mathrm{N}_{6,6,6,6,6}\right]\left[\mathrm{C}_{8: 0}\right]$, methyltrioctylammonium laurate $\left[\mathrm{N}_{8,8,8,1}\right]\left[\mathrm{C}_{12: 0}\right]$, methyltrioctylammonium palmitate $\left[\mathrm{N}_{8,8,8,8}\right]\left[\mathrm{C}_{16: 0}\right]$, tetrahexylammonium palmitate $\left[\mathrm{N}_{6,6,6,6,6}\right]\left[\mathrm{C}_{16: 0}\right]$, methyltrioctylammonium stearate $\left[\mathrm{N}_{8,8,8,1}\right]\left[\mathrm{C}_{18: 0}\right]$ and methyltrioctylammonium oleate $\left[\mathrm{N}_{8,8,8,1}\right]\left[\mathrm{C}_{18: 1}\right]$. In addition, isothermal experiments were performed in order to compare their results with those of the model-free methods and determine whether the two methodologies are in good agreement. To the best of our knowledge, no studies focusing on model-free methodology with FAILs have been reported in the literature.

\section{Experimental}

\subsection{Chemicals}

Eight fatty acid-based ionic liquids (FAILs), Table 1, were synthesized using a salt metathesis reaction according to the methodology described in Battez et al. [106]. The details related to their identification 
through ${ }^{1} \mathrm{H}$ and ${ }^{13} \mathrm{C}$ NMR (nuclear magnetic resonance) and FTIR (Fourier-transform infrared spectroscopy) analyses can also be found in Battez et al. [106], Blanco et al. [61] and Sernaglia et al. [69]. Methyltrioctylammonium bromide ( $\geq 97 \%)$ and tetrahexylammonium bromide ( $\geq 99 \%)$ ionic liquids were employed as cation precursor. In addition, several natural fatty acids: hexanoic ( $\geq 98 \%)$, octanoic $(\geq 98 \%)$, lauric ( $\geq 98 \%$ ), palmitic $(\geq 98 \%)$, stearic $(\geq 98 \%)$ and oleic $(\geq 95 \%)$ were used as anion precursors. Both cation and anion precursors were supplied by Sigma-Aldrich and employed without any further purification. After the above-mentioned synthesis procedure, a bright orange liquid product was obtained in all cases, with the molar yield ranging from $85-95 \%$. In addition, a Metrohm 899 coulometer Karl Fischer titration was used to determine the water content of the ionic liquids, obtaining values ranging between 1 and 3\%. Finally, the nature of the synthesis employed means that traces of halides could also be present in the final product. Fig. 1 shows the chemical structure and acronym of the 8 FAILs.

Table 1 Chemical description of the ILs used.

\begin{tabular}{llcc}
\hline \multicolumn{1}{c}{ IUPAC name } & Acronym & $\begin{array}{c}\text { Molecular weight } \\
(\mathrm{g} / \mathrm{mol})\end{array}$ & Empirical formula \\
\hline Methyltrioctylammonium hexanoate & {$\left[\mathrm{N}_{8,8,8,1}\right]\left[\mathrm{C}_{6: 0}\right]$} & 483 & $\mathrm{C}_{31} \mathrm{H}_{65} \mathrm{NO}_{2}$ \\
Methyltrioctylammonium octanoate & {$\left[\mathrm{N}_{8,8,8,1}\right][\mathrm{C}: 0]$} & 511 & $\mathrm{C}_{33} \mathrm{H}_{69} \mathrm{NO}_{2}$ \\
Tetrahexylammonium octanoate & {$\left[\mathrm{N}_{6,6,6,6,6}\right]\left[\mathrm{C}_{8: 0}\right]$} & 496 & $\mathrm{C}_{32} \mathrm{H}_{66} \mathrm{NO}_{2}$ \\
Methyltrioctylammonium laurate & {$\left[\mathrm{N}_{8,8,8,1}\right]\left[\mathrm{C}_{12: 0}\right]$} & 567 & $\mathrm{C}_{37} \mathrm{H}_{77} \mathrm{NO}_{2}$ \\
Methyltrioctylammonium palmitate & {$\left[\mathrm{N}_{8,8,8,1}\right]\left[\mathrm{C}_{16: 0}\right]$} & 623 & $\mathrm{C}_{41} \mathrm{H}_{85} \mathrm{NO}_{2}$ \\
Tetrahexylammonium palmitate & {$\left[\mathrm{N}_{6,6,6,6}\right]\left[\mathrm{C}_{16: 0}\right]$} & 608 & $\mathrm{C}_{40} \mathrm{H}_{82} \mathrm{NO}_{2}$ \\
Methyltrioctylammonium stearate & {$\left[\mathrm{N}_{8,8,8,1}\right]\left[\mathrm{C}_{18: 0}\right]$} & 651 & $\mathrm{C}_{43} \mathrm{H}_{89} \mathrm{NO}_{2}$ \\
Methyltrioctylammonium oleate & {$\left[\mathrm{N}_{8,8,8,1}\right]\left[\mathrm{C}_{18: 1}\right]$} & 649 & $\mathrm{C}_{43} \mathrm{H}_{87} \mathrm{NO}_{2}$ \\
\hline
\end{tabular}
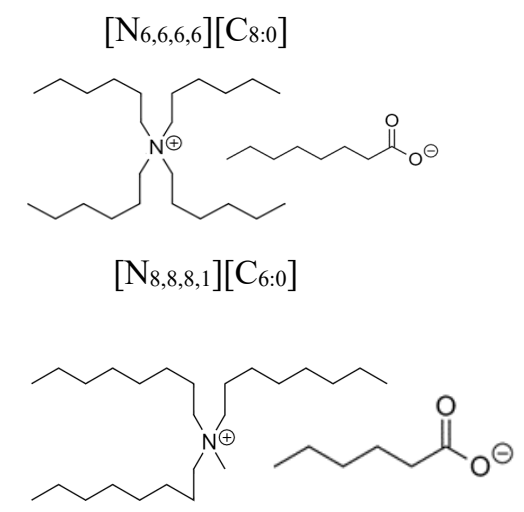

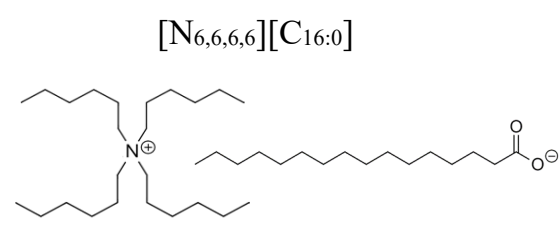

$\left[\mathrm{N}_{8,8,8,1}\right]\left[\mathrm{C}_{8: 0}\right]$

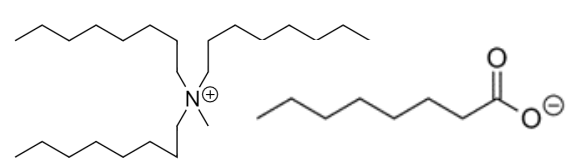



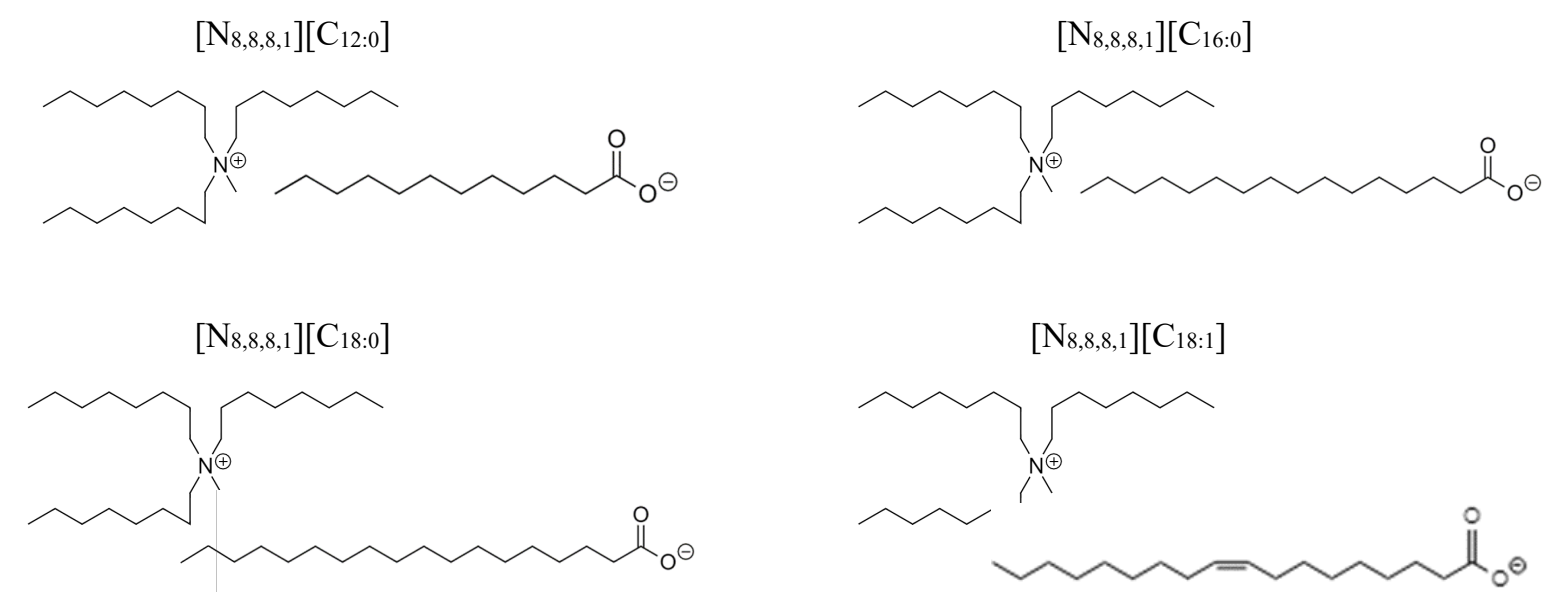

Fig. 1 Chemical structures and acronyms of the FAILs.

\subsection{Thermal analysis}

A TA Instruments DSC SDT Q600 Thermogravimetric Analyzer (TGA) \& Differential Scanning Calorimeter (DSC) was employed to perform the thermal analysis. In addition, TA Instruments Universal Analysis 2000 version software was employed to analyse the obtained results. This equipment has the ability to operate in both dynamic and isothermal modes. Dynamic tests were performed with 29-31 mg of each FAIL under a dry nitrogen atmosphere (flow of $50 \mathrm{~mL} / \mathrm{min}$ ), using four different heating rates $(5,10$, 15 and $20 \mathrm{~K} \cdot \mathrm{min}^{-1}$ ) from 30 to $600{ }^{\circ} \mathrm{C}$. Isothermal experiments were also carried out under this mentioned atmosphere at three different temperatures $\left(100,150\right.$ and $\left.200{ }^{\circ} \mathrm{C}\right)$ for $12 \mathrm{~h}$ and at lower temperature $\left(80^{\circ} \mathrm{C}\right)$ for $24 \mathrm{~h}$. Using TGA (thermogravimetric analysis) and DTG (differential thermogravimetry) data, several parameters could be obtained:

- $T_{\text {onset }}$ determined as the point of intersection of the starting-mass baseline and the tangent to the TGA curve at the point of maximum slope $\left({ }^{\circ} \mathrm{C}\right)$.

- Tendset: intersection point of the curve segment after the inflection occurs and the tangent to the TGA curve at the point of maximum slope $\left({ }^{\circ} \mathrm{C}\right)$.

- $T_{10 \%}$ : temperature equivalent to $10 \%$ of mass loss $\left({ }^{\circ} \mathrm{C}\right)$.

- $T_{50 \%}$ : temperature equivalent to $50 \%$ of mass $\operatorname{loss}\left({ }^{\circ} \mathrm{C}\right)$.

- $W_{\text {total loss: }}$ mass loss at the end of the experiment (\%).

- $W_{\text {onset: }}$ mass loss at decomposition onset temperature (\%). 


\subsection{Kinetic modelling}

The main recommendations of the ICTAC Kinetics Committee were followed with the aim of evaluating the multi-step thermal decomposition kinetics, as well as the measurement and parametrization of the process rates $[96,97,107]$. The rate in a thermal-decomposition process can be defined through two parameters: temperature $(\mathrm{T})$ and the extent of reaction or conversion $(\alpha)$, Eq. (1).

$$
\frac{d \alpha}{d t}=k(T) f(\alpha)
$$

In a thermogravimetric (TG) experiment, where the variation of mass versus temperature is obtained, the extent of reaction is calculated using the following Eq. (2) [96, 104, 108, 109]:

$$
\alpha=\frac{m_{0}-m_{t}}{m_{o}-m_{e}}
$$

where: $m_{0}$ is the initial mass, $m_{t}$ is the mass at time $t$ and $m_{e}$ is the mass at the end of the test. It should be noted that the conversion $(\alpha)$ can vary from 0 (absence of mass loss) to 1 (complete mass loss). The parameter $m_{\mathrm{e}}$ depends on the atmosphere and the type of substance among other factors; a zero value was assumed for this parameter in this study due to the nature of the FAILs.

The temperature dependence of the rate constant, k(T), in Eq. (1) is described by the Arrhenius Eq. (3) [97].

$$
k(T)=A \cdot \exp \frac{-E_{a}}{R T}
$$

where $\mathrm{A}$ is the pre-exponential factor, $E_{a}$ is the activation energy, $\mathrm{R}$ is the gas constant and $T$ is the absolute temperature. Merging Eq. (1) and Eq. (3), the Eq. (4) can be obtained:

$$
\frac{d \alpha}{d t}=A \cdot \exp \frac{-E_{a}}{R T} f(\alpha)
$$

In this study, kinetic analysis is based on non-isothermal thermogravimetric experiments, so the above expression can be transformed into a non-isothermal rate expression describing reaction rates as a function of temperature at a constant heating rate, $\beta$, Eq. (5):

$$
\frac{d \alpha}{d T}=\frac{A}{\beta} \cdot \exp \frac{-E_{a}}{R T} f(\alpha)
$$

Based on the above equation, model-free isoconversional methods allow the estimation of the activation energy as a function of $\alpha$ without choosing the reaction model. Their basic assumption is the isoconversional principle (the reaction rate for a constant $\alpha$ depends only on temperature). There are a variety of isoconversional methods and two different mathematical categories [95, 98, 99, 102, 104, 109-111] can be 
distinguished: i) integral, such as Kissinger-Akahira-Sunose (KAS) and Flynn-Wall-Ozawa (FWO) and ii) differential, the Friedman and Kissinger methods being the most common ones. Therefore, three of these abovementioned isoconversional methods are used in this work (Table 2).

Table 2 Isoconversional methods employed in this research.

\begin{tabular}{llcl}
\hline $\begin{array}{c}\text { Model free } \\
\text { methods }\end{array}$ & Type & Expression & Ref. \\
\hline FWO & Integral & $\log (\beta)=\log \left(\frac{A E}{g(\alpha)}\right)-2.315-\frac{0.457 E_{a}}{R T}$ & {$[95,99,110,111]$} \\
KAS & Integral & $\ln \left(\frac{\beta}{T^{2}}\right)=\ln \left(\frac{A R}{E_{\alpha} g(\alpha)}\right)-\frac{E_{a}}{R T}$ & {$[95,99,104,109,110]$} \\
\hline Friedman & Differential & $\ln \left(\frac{d \alpha}{d t}\right)_{\alpha}=\ln (A f(\alpha))-\frac{E_{a}}{R T}$ & {$[95,110,111]$} \\
\hline
\end{tabular}

For applying these methods, it is necessary to use at least three different heating rates. It is important to bear in mind what happens in a thermogravimetric experiment in order to choose the appropriate heating rates. The resultant mass loss should be the combination of thermal decomposition and evaporation kinetics occurring simultaneously $[71,80-86]$. Considering that both the decomposition and evaporation rates grow exponentially with temperature (although the decomposition rate is more temperature sensitive than the evaporation rate), the utilization of wide temperature ranges and high heating rates leads to a process in which the thermal decomposition should control the overall mass loss [82]. Therefore, the heating rates used in this research are greater than $5 \mathrm{~K} \cdot \mathrm{min}^{-1}$ with the with the objective of ensuring that thermal decomposition is the predominant process, making Eq. (1) negligible. Finally, this methodology allows the estimation of the time $\left(t_{\alpha}\right)$ needed to reach a given conversion $(\alpha)$ under an arbitrary isothermal experiment $\left(T_{0}\right)$, Eq. (6):

$$
t_{\alpha}=\frac{\int_{0}^{T_{\alpha}} e^{-E_{\alpha} / R T} d T}{\beta e^{-E_{\alpha} / R T_{0}}}
$$




\section{3. Results and discussion}

\subsection{Thermal decomposition}

3 The TG and DTG graphs of the 8 FAILs are plotted in Figs. 2 and 3, respectively. All studied substances

4 show a multi-step degradation mechanism, which can be seen in Fig. 3, where the DTG curves have an $5 \quad$ irregular shape due the overlapping mass loss processes.

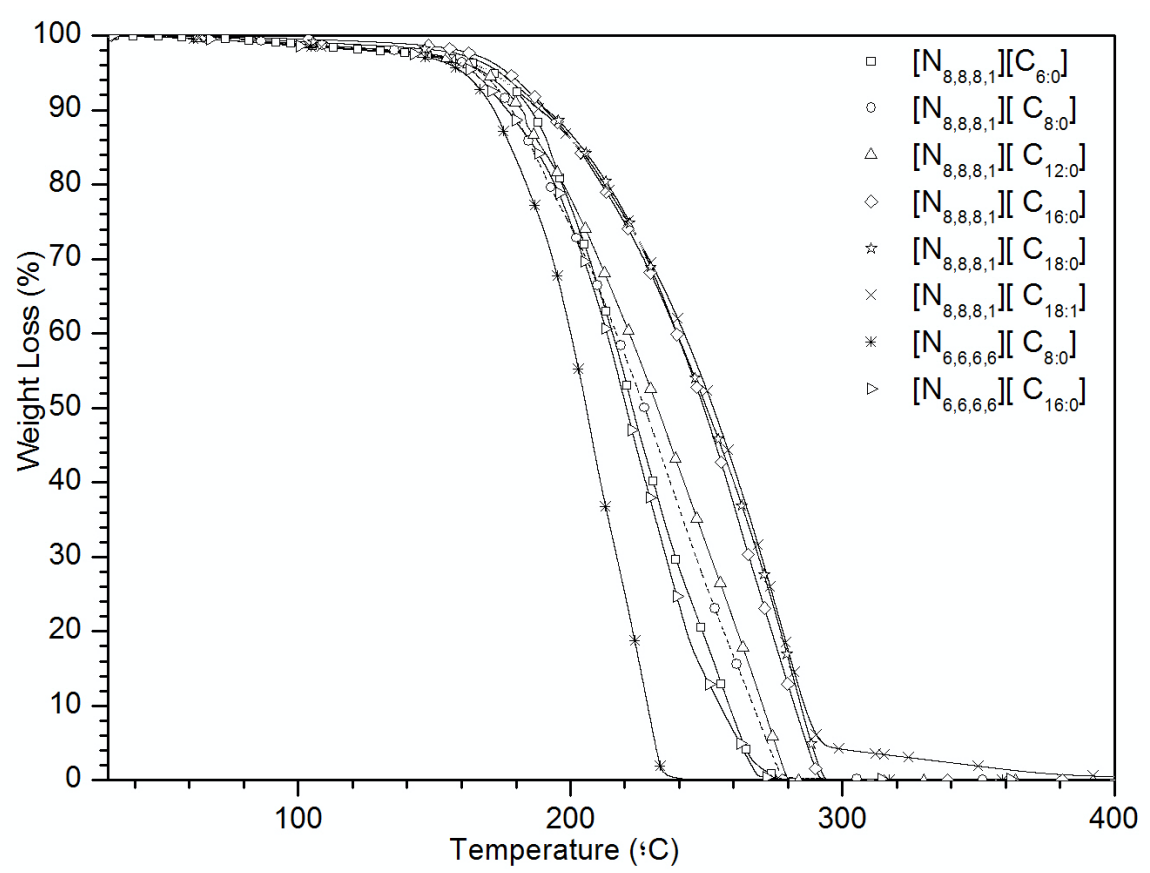

8 Fig. 2 Full scale TGA for all FAILs obtained under nitrogen atmosphere at a heating rate of $10 \mathrm{~K} \cdot \mathrm{min}^{-1}$.

10 Although the thermal stability of ILs is usually determined by the coordinating ability of the anion [112-

11 114], in view of these results it can be concluded that the mechanism of thermal decomposition was also 12 affected by the cation. This conclusion can be drawn from Figs. 2-3, since the two samples with $\left[\mathrm{N}_{6,6,6,6,6}\right]^{+}$ 13 cation presented the lowest thermal stability (curves shifted to the left in Fig. 2 or higher peaks in Fig. 3).

14 On the other hand, when the cation is the same, the anion with the shortest chain length seems to be least 15 thermally stable. Two different groups can be observed for the FAILs with $\left[\mathrm{N}_{8,8,8,1}\right]^{+}$cation: one for the $16\left[\mathrm{C}_{6: 0}\right]^{-},\left[\mathrm{C}_{8: 0}\right]^{-}$and $\left[\mathrm{C}_{12: 0}\right]^{-}$anions (shifted to the left) and another for the $\left[\mathrm{C}_{16: 0}\right]^{-},\left[\mathrm{C}_{18: 0}\right]^{-}$and $\left[\mathrm{C}_{18: 1}\right]^{-}$anions 17 (shifted to the right). Furthermore, these differences are observed in Fig. 3, since the derivative curves present different shapes. Several authors [115-116] have determined multi-step thermal decomposition reactions for different ILs due to the separate decomposition of cation and anion. The two groups of FAILs are sharing the same cation, so the different trends may be based on the length of the alkyl chain of the 
1 anion. In this particular case, FAILs with shorter chain anions show a more irregular shape in DTG curves.

2 This multi-step mechanism may well be related to the increase in the anion-cation electrostatic interaction.

3 As the carbon chain increases in length no shoulders are observed in the DTG curve and a single-step model dominates the process.

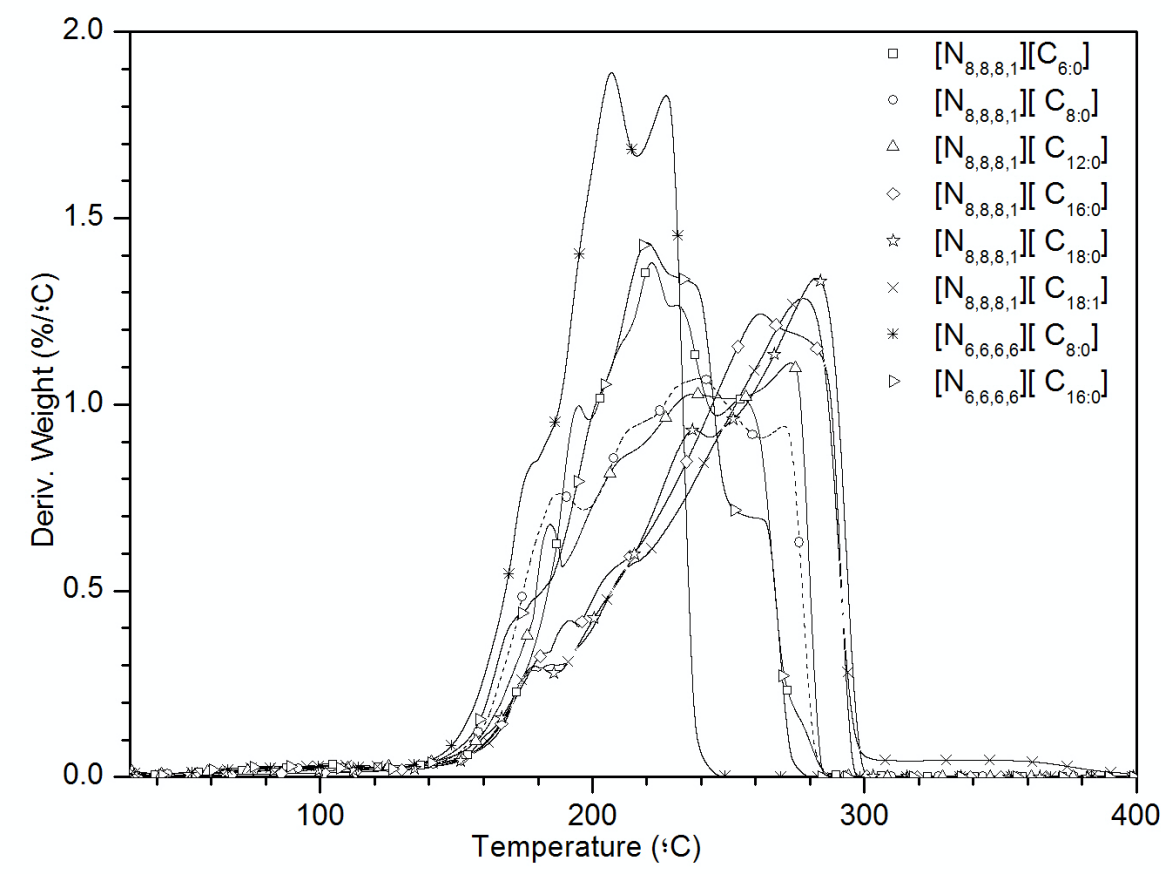

5

8 Therefore, the thermal stability of FAILs here studied is controlled by both the cation and anion, the cation 9 effect being more important, since samples including the $\left[\mathrm{N}_{6,6,6,6}\right]^{+}$cation were the most thermally unstable.

10 Table 3 shows several parameters obtained from TG plots, such as: $T_{\text {onset, }}, T_{\text {endset, }}, T_{10 \%}, T_{50 \%}, W_{\text {total loss }}$ and $11 W_{\text {onset. }}$ Most of the samples have an onset decomposition temperature $\left(T_{\text {onset }}\right)$ below $200{ }^{\circ} \mathrm{C}$, with $12\left[\mathrm{~N}_{8,8,8,1}\right]\left[\mathrm{C}_{16: 0}\right],\left[\mathrm{N}_{8,8,8,1}\right]\left[\mathrm{C}_{18: 0}\right]$ and $\left[\mathrm{N}_{8,8,8,1}\right]\left[\mathrm{C}_{18: 1}\right]$ registering the best values with respect to this parameter, 13 probably due to the slight influence of their longer alkyl chains in the anions [102, 109]. 
Table 3 Thermal results from dynamic scans obtained under nitrogen atmosphere at $10 \mathrm{~K} \cdot \mathrm{min}^{-1}$.

\begin{tabular}{lcccccc}
\hline \multicolumn{1}{c}{ FAILs } & $T_{\text {onset }}\left({ }^{\circ} \mathrm{C}\right)$ & $T_{10 \%}\left({ }^{\circ} \mathrm{C}\right)$ & $T_{50 \%}\left({ }^{\circ} \mathrm{C}\right)$ & $T_{\text {endset }}\left({ }^{\circ} \mathrm{C}\right)$ & $W_{\text {total loss }}(\%)$ & $W_{\text {onset }}(\%)$ \\
\hline$\left[\mathrm{N}_{8,8,8,1}\right]\left[\mathrm{C}_{6: 0}\right]$ & 190 & 184 & 222 & 262 & 99.56 & 10.52 \\
{$\left[\mathrm{~N}_{8,8,8,1}\right]\left[\mathrm{C}_{8: 0}\right]$} & 177 & 178 & 227 & 274 & 99.70 & 9.68 \\
{$\left[\mathrm{~N}_{8,8,8,1}\right]\left[\mathrm{C}_{12: 0}\right]$} & 182 & 192 & 232 & 280 & 99.82 & 9.67 \\
{$\left[\mathrm{~N}_{8,8,8,1}\right]\left[\mathrm{C}_{16: 0}\right]$} & 200 & 190 & 249 & 290 & 99.44 & 13.88 \\
{$\left[\mathrm{~N}_{8,8,8,1}\right]\left[\mathrm{C}_{18: 0}\right]$} & 199 & 190 & 250 & 293 & 100.00 & 12.44 \\
{$\left[\mathrm{~N}_{8,8,8,1}\right]\left[\mathrm{C}_{18: 1}\right]$} & 200 & 186 & 252 & 292 & 98.61 & 13.49 \\
{$\left[\mathrm{~N}_{6,6,6,6}\right]\left[\mathrm{C}_{8: 0}\right]$} & 177 & 172 & 206 & 232 & 99.62 & 14.06 \\
{$\left[\mathrm{~N}_{6,6,6,6}\right]\left[\mathrm{C}_{16: 0}\right]$} & 187 & 176 & 220 & 256 & 99.34 & 15.17 \\
\hline
\end{tabular}

2

3 The same trend is also observed with $T_{\text {endset }}, T_{10 \%}$ and $T_{50 \%}$ parameters. In addition, mass loss of almost

$4 \quad 100 \%$ has been detected for all samples at the end of the experiment. In view of all these thermal parameters,

5 the sample $\left[\mathrm{N}_{6,6,6,6}\right]\left[\mathrm{C}_{8: 0}\right]$ has the lowest thermal stability. In addition, all the FAILs here studied exhibited

6 lower thermal stability under a nitrogen atmosphere than the traditional ILs tested previously in lubrication

7 studies $[102,104,105,109]$, particularly when compared to those containing the [NTf $]^{-}$anion.

9 3.2. Kinetic analysis

10 Fig. 4 shows different TG plots obtained with four heating rates $\left(5,10,15\right.$ and $\left.20 \mathrm{~K} \cdot \mathrm{min}^{-1}\right)$. This is 11 mandatory for the application of the different model-free kinetics methods because at least three dynamic 12 curves with different heating rates are required. These methods are in agreement with the isoconversional 13 principle which states that the reaction rate at a constant extent of conversion is dependent only on the 14 temperature. This implies that curves plotted at different heating rates cannot intersect if the model is to be 15 considered valid, at least in the conversion range over which activation energy $\left(E_{a}\right)$ remained constant [97, $16104,109,117]$. In addition, thermal stability was lower with decreasing values of $\beta$ for the eight FAILs 17 here studied. This is possibly related to the higher sensitivity of this decomposition reaction at lower heating 18 rates, which agrees with Kok et al. [118]. In addition, it seems that the thermal stability at the lowest heating 19 rate $\left(5 \mathrm{~K} \cdot \mathrm{min}^{-1}\right)$ differs from that under the remaining heating rates $\left(10,15\right.$ and $\left.20 \mathrm{~K} \cdot \mathrm{min}^{-1}\right)$, especially for 20 the FAILs $\left[\mathrm{N}_{8,8,8,1}\right]\left[\mathrm{C}_{6: 0}\right],\left[\mathrm{N}_{8,8,8,1}\right]\left[\mathrm{C}_{8: 0}\right]$ and $\left[\mathrm{N}_{8,8,8,1}\right]\left[\mathrm{C}_{12: 0}\right]$. This may be because the shorter alkyl chains of 21 these FAILs facilitate the decomposition reaction. Another possible explanation for this result could be 22 that at the lowest heating rate $\left(5 \mathrm{~K} \cdot \mathrm{min}^{-1}\right)$, the contribution of evaporation to the overall rate of mass loss 23 is not entirely negligible [71]. 
1 The fits corresponding to the application of the three selected isoconversional methods to the dynamic TG

2 data for all the studied FAILs exhibit good linearity, with $\mathrm{R}^{2} \geq 0.90$ being obtained in all cases. This 3 isoconversional methodology was applied in all cases for fourteen $\alpha$ values between 1 and $99 \%$. Constant

4 activation energy values should be expected in the case of a single-step reaction. In this case, the activation 5 energy remained practically constant only when the $\alpha$ values were in the range $30-60 \%$ (see Table 4 ),

6 probably due to the complexity of the thermal process. In order to determine the apparent degradation 7 activation energies, calculations using TG and DTG dynamic data must be performed: $\ln (d \alpha / d t)$ 8 (Friedman), $\ln (\beta / T)(\mathrm{KAS})$ and $\log \beta$ (FWO) against 1/T were respectively plotted. 

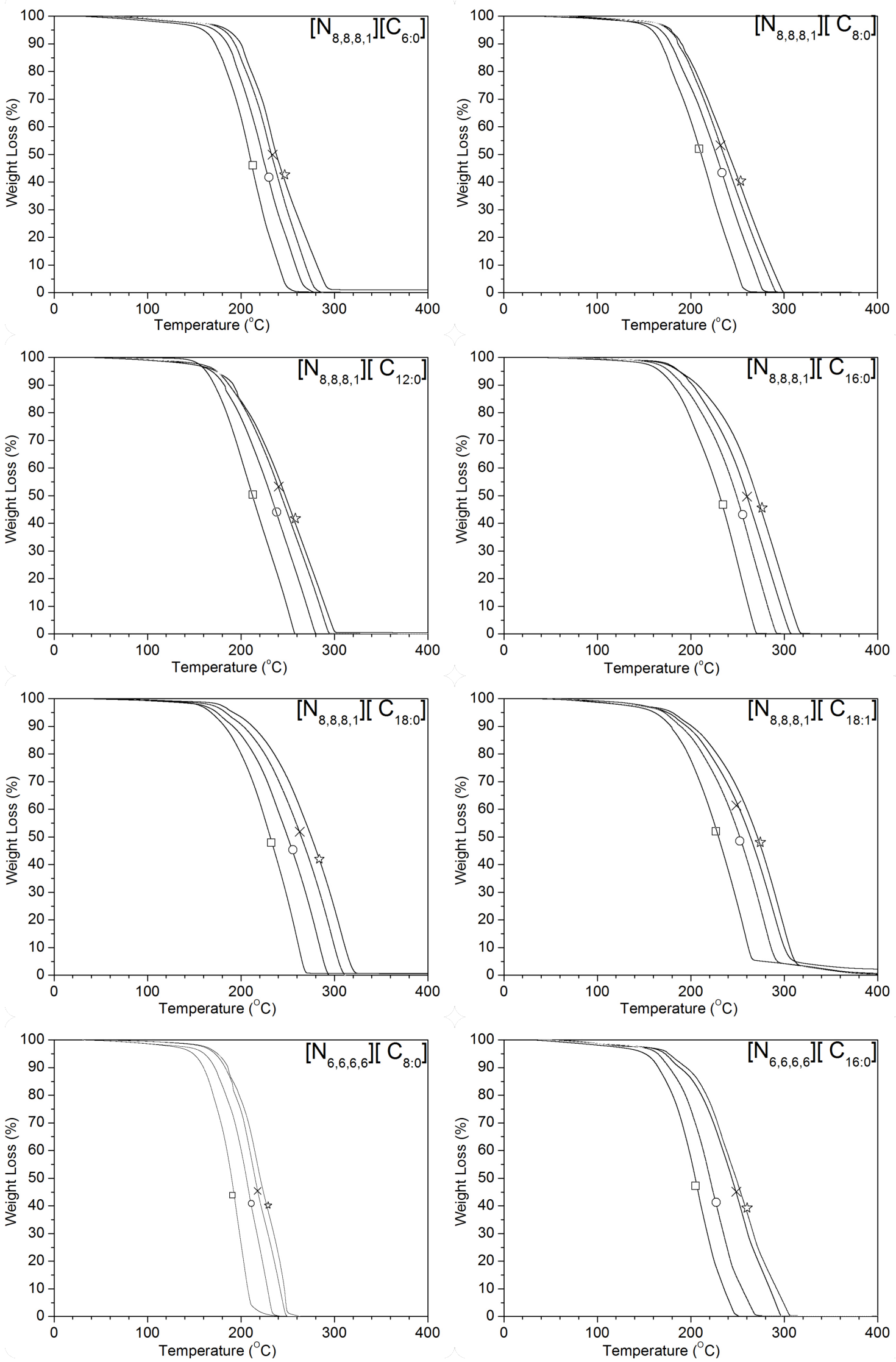

Fig. 4 TGA of all ILs studied under nitrogen atmosphere at heating rates of:

() 5, (O) 10, (×) 15 and («) $20 \mathrm{~K} \cdot \mathrm{min}^{-1}$. 
1 The apparent activation energy, obtained as the slope of the fitting equation of each isoconversional method,

2 and for each conversion degree, is presented in Table 4. In view of the results, the activation energy values

3 calculated from the three dynamic methods are quite similar, being slightly higher in most cases for KAS

4 and FWO methodologies. experiments with heating rates of $5,10,15$ and $20 \mathrm{~K} \cdot \mathrm{min}^{-1}$.

\begin{tabular}{|c|c|c|c|c|c|}
\hline \multirow{2}{*}{ FAILs } & \multirow{2}{*}{ Methods } & \multicolumn{4}{|c|}{ Conversion, $\alpha(\%)$} \\
\hline & & 30 & 40 & 50 & 60 \\
\hline \multirow{3}{*}[\mathrm{N}_{8,8,8,1}]{$\left[\mathrm{C}_{6: 0}\right]$} & KAS & 87.43 & 89.41 & 88.88 & 83.04 \\
\hline & FWO & 90.50 & 92.49 & 90.5 & 86.69 \\
\hline & Friedman & 85.49 & 97.35 & 78.23 & 70.49 \\
\hline \multirow{3}{*}[\mathrm{N}_{8,8,8,1}]{$\left[\mathrm{C}_{8: 0}\right]$} & KAS & 90.81 & 90.44 & 87.87 & 83.91 \\
\hline & FWO & 93.85 & 93.67 & 91.38 & 87.77 \\
\hline & Friedman & 97.21 & 88.12 & 82.66 & 75.54 \\
\hline \multirow{3}{*}[\mathrm{N}_{8,8,8,1}]{$\left[\mathrm{C}_{12: 0}\right]$} & KAS & 88.17 & 87.57 & 84.95 & 86.82 \\
\hline & FWO & 83.84 & 77.67 & 75.95 & 75.32 \\
\hline & Friedman & 66.10 & 65.82 & 70.61 & 71.55 \\
\hline \multirow{3}{*}[\mathrm{N}_{8,8,8,1}]{$\left[\mathrm{C}_{16: 0}\right]$} & KAS & 67.26 & 69.27 & 71.77 & 72.19 \\
\hline & FWO & 71.84 & 73.93 & 76.46 & 77.01 \\
\hline & Friedman & 68.39 & 77.04 & 78.29 & 72.3 \\
\hline \multirow{3}{*}[\mathrm{N}_{8,8,8,1}]{$\left[\mathrm{C}_{18: 0}\right]$} & KAS & 67.22 & 65.10 & 63.42 & 62.97 \\
\hline & FWO & 71.85 & 70.01 & 68.58 & 68.3 \\
\hline & Friedman & 78.98 & 72.25 & 57.69 & 63.84 \\
\hline \multirow{3}{*}[\mathrm{N}_{8,8,8,1}]{$\left[\mathrm{C}_{18: 1}\right]$} & KAS & 70.62 & 67.28 & 63.94 & 66.50 \\
\hline & FWO & 75.01 & 72.02 & 71.15 & 71.59 \\
\hline & Friedman & 61.44 & 63.52 & 66.74 & 71.31 \\
\hline \multirow{3}{*}[\mathrm{N}_{6,6,6,6}]{$\left[\mathrm{C}_{8: 0}\right]$} & KAS & 73.77 & 78.04 & 76.83 & 71.93 \\
\hline & FWO & 77.47 & 81.62 & 80.56 & 75.99 \\
\hline & Friedman & 81.31 & 81.43 & 69.23 & 50.44 \\
\hline \multirow{3}{*}[\mathrm{N}_{6,6,6,6,6}]{$\left[\mathrm{C}_{16: 0}\right]$} & KAS & 56.71 & 55.12 & 51.41 & 48.92 \\
\hline & FWO & 61.52 & 60.15 & 56.75 & 54.51 \\
\hline & Friedman & 53.51 & 44.46 & 38.64 & 43.58 \\
\hline
\end{tabular}

8 Average values of activation energy were obtained as the mean values of those corresponding to the

9 different conversion values between $30-60 \%$ for each isoconversional method, and results are shown in

10 Table 5. In addition, the resultant $E_{a}$ is calculated as the average value of KAS, FWO and Friedman results,

11 and its uncertainty as a weighted average of the uncertainties associated with each model, where the weight

12 of each model has been inversely proportional to its variance. Finally, the dispersion between models is

13 showed through the variance in the last column. These results indicate that the activation energy values are 
1 quite similar, regardless of the methodology, especially in the case of the KAS and FWO methods.

2 Furthermore, the error does not exceed the $10 \%$ range in most cases. Analysing the observed trend, the two

3 samples with cation $\left[\mathrm{N}_{6,6,6,6}\right]^{+}$present the lowest $E_{a}$ mean values.

4 On the other hand, there seem to be higher $E_{a}$ values in the group of samples containing the anions with the

5 shortest chain length and the same cation $\left[\mathrm{N}_{8,8,8,1}\right]\left[\mathrm{C}_{6: 0}\right]<\left[\mathrm{N}_{8,8,8,1}\right]\left[\mathrm{C}_{8: 0}\right]$ versus the samples with longer

6 anion chain length : $\left[\mathrm{N}_{8,8,8,1}\right]\left[\mathrm{C}_{12: 0}\right]>\left[\mathrm{N}_{8,8,8,1}\right]\left[\mathrm{C}_{16: 0}\right]>>\left[\mathrm{N}_{8,8,8,1}\right]\left[\mathrm{C}_{18: 0}\right]=\left[\mathrm{N}_{8,8,8,1}\right]\left[\mathrm{C}_{18: 1}\right]$, in which the

7 thermal stability decreases with the anion chain length. A parallel difference in behaviour between the two

8 groups has already been reported for another physical property, namely surface tension, by Blanco et al.

9 [61]. These results strongly suggest that the thermal degradation mechanism depends on the alkyl chain

10 length of the anion, the electrostatic force being stronger for $\left[\mathrm{N}_{8,8,8,1}\right]\left[\mathrm{C}_{6: 0}\right]$ and $\left[\mathrm{N}_{8,8,8,1}\right]\left[\mathrm{C}_{8: 0}\right]$.

Table 5 Average activation energy $(\mathrm{kJ} / \mathrm{mol})$ from different models.

\begin{tabular}{cccccc}
\hline \multirow{2}{*}{ FAILs } & KAS & FWO & Friedman & Average & $\begin{array}{c}\text { Dispersion } \\
\text { Models } \\
\text { (variance) }\end{array}$ \\
\cline { 2 - 6 } & & $90 \pm 3$ & $82 \pm 8$ & $87 \pm 3$ & 16 \\
\hline$\left[\mathrm{N}_{8,8,8,1}\right]\left[\mathrm{C}_{6: 0}\right]$ & $87 \pm 3$ & $92 \pm 3$ & $83 \pm 9$ & $88 \pm 4$ & 20 \\
{$\left[\mathrm{~N}_{8,8,8,1}\right]\left[\mathrm{C}_{8: 0}\right]$} & $88 \pm 4$ & $78 \pm 4$ & $69 \pm 3$ & $78 \pm 2$ & 81 \\
{$\left[\mathrm{~N}_{8,8,8,1}\right]\left[\mathrm{C}_{12: 0}\right]$} & $87 \pm 2$ & $75 \pm 3$ & $74 \pm 5$ & $73 \pm 3$ & 7 \\
{$\left[\mathrm{~N}_{8,8,8,1}\right]\left[\mathrm{C}_{16: 0}\right]$} & $70 \pm 3$ & $70 \pm 2$ & $63 \pm 4$ & $66 \pm 2$ & 13 \\
{$\left[\mathrm{~N}_{8,8,8,1}\right]\left[\mathrm{C}_{18: 0}\right]$} & $65 \pm 2$ & $72 \pm 2$ & $66 \pm 5$ & $68 \pm 3$ & 10 \\
{$\left[\mathrm{~N}_{8,8,8,1}\right]\left[\mathrm{C}_{18: 1}\right]$} & $67 \pm 3$ & $79 \pm 3$ & $71 \pm 15$ & $75 \pm 3$ & 16 \\
{$\left[\mathrm{~N}_{6,6,6,6}\right]\left[\mathrm{C}_{8: 0}\right]$} & $75 \pm 3$ & $58 \pm 4$ & $45 \pm 7$ & $52 \pm 4$ & 43 \\
{$\left[\mathrm{~N}_{6,6,6,6}\right]\left[\mathrm{C}_{16: 0}\right]$} & $53 \pm 4$ & & & &
\end{tabular}

\subsection{Isothermal analysis}

14 In order to complete the thermal study [95, 104, 109], certain isothermal tests were conducted for some 15 FAILs: $\left[\mathrm{N}_{8,8,8,1}\right]\left[\mathrm{C}_{6: 0}\right],\left[\mathrm{N}_{8,8,8,1}\right]\left[\mathrm{C}_{12: 0}\right],\left[\mathrm{N}_{6,6,6,6,6}\right]\left[\mathrm{C}_{16: 0}\right]$, and $\left[\mathrm{N}_{8,8,8,1}\right]\left[\mathrm{C}_{18: 1}\right]$ under an inert atmosphere. Taking 16 into account the obtained results (Fig. 5), all FAIL samples were almost totally decomposed (conversion 17 values above $90 \%$ ) after 600 min of testing at $150{ }^{\circ} \mathrm{C}$. Meanwhile, the 4 FAILs were totally decomposed at $18200{ }^{\circ} \mathrm{C}$ when half of the experiment had been performed, with $\left[\mathrm{N}_{8,8,8,1}\right]\left[\mathrm{C}_{12: 0}\right]$ and $\left[\mathrm{N}_{6,6,6,6,6}\right]\left[\mathrm{C}_{16: 0}\right]$ being completely decomposed in less than $100 \mathrm{~min}$. These results proved that FAILs in the isothermal experiments showed appreciable decomposition at temperatures significantly lower than the values

21 indicated by the $T_{\text {onset }}$ calculated from TGA results. Although all samples are fairly stable at $100{ }^{\circ} \mathrm{C}$ under 22 a nitrogen atmosphere and $12 \mathrm{~h}$ testing, a new isothermal test was conducted for $24 \mathrm{~h}$ at $80{ }^{\circ} \mathrm{C}$ with the aim 23 of confirming the previous results. Comparing the results, the isothermal tests are in agreement with the 
1 results from the dynamic tests. The influence of the cation was confirmed, tetrahexylammonium palmitate $2\left(\left[\mathrm{~N}_{6,6,6,6}\right]\left[\mathrm{C}_{16: 0}\right]\right)$ being the FAIL that presents the greatest decomposition under the isothermal test at 100 3 ${ }^{\circ} \mathrm{C}$.
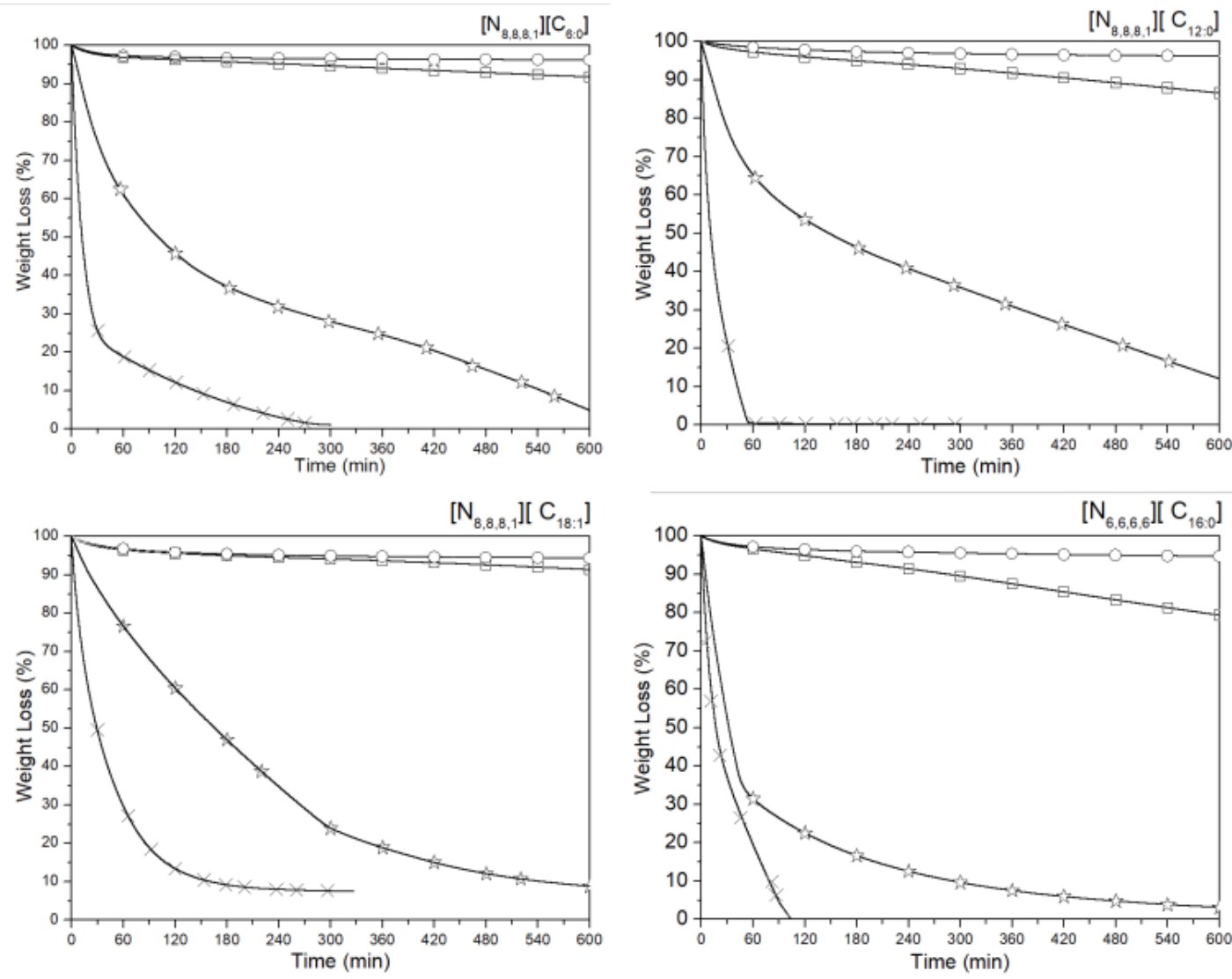

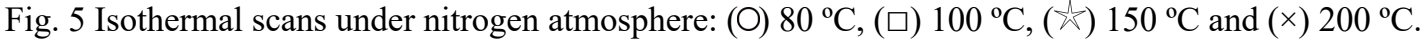

\subsection{Isoconversional modelling}

8 The activation energy $\left(E_{a}\right)$, conversion $(\alpha)$ and decomposition time $\left(t_{\alpha}\right)$ were estimated as a function of an

9 arbitrary temperature $\left(T_{0}\right)$ by different model-free kinetics methodologies using TGA experimental data under a nitrogen atmosphere (see Table 4). This implies using Eq. (6) with non-isothermal kinetic data in order to predict the FAIL behaviour under isothermal conditions at that temperature $\left(T_{0}\right)$. It is important to bear in mind that this arbitrary temperature $\left(T_{0}\right)$ should not be far away from the experimental temperature ( $T_{\alpha}$ ) over the range of $T_{\alpha}$ in which the $E_{a}$ remained practically constant, in order to avoid significant relative errors [119]. Therefore, the thermal stability of ionic liquids could be estimated by using short-term nonisothermal thermogravimetric measurements at different heating rates with the objective of applying a kinetic model and obtaining kinetic parameters. In order to solve the mentioned equation, the integral is approximated using the equation proposed by Wanjun et al. [120]. Finally, the necessary time at which 
1 each conversion value is reached at a given temperature $\left(T_{0}=200^{\circ} \mathrm{C}\right)$ was estimated $[104,109,121,122]$

2 and the results are shown in Fig. 6.
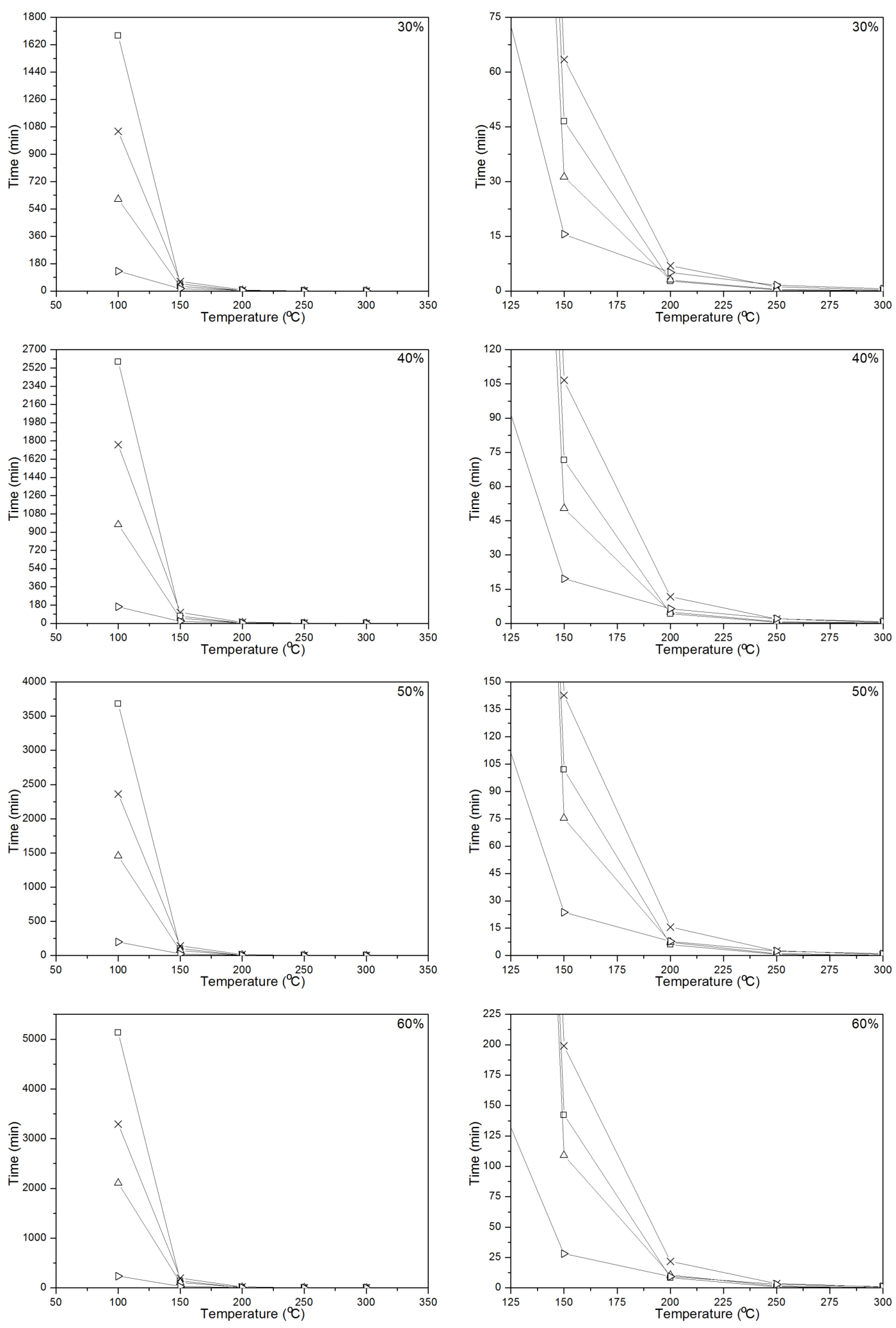

4 Fig. 6 Estimated isoconversional curves (zoom on the right) at 30, 40, 50 and $60 \%$ of conversion for :

$(\times)\left[\mathrm{N}_{8,8,8,1}\right]\left[\mathrm{C}_{18: 1}\right],(\triangle)\left[\mathrm{N}_{8,8,8,1}\right]\left[\mathrm{C}_{12: 0}\right],(\square)\left[\mathrm{N}_{8,8,8,1}\right]\left[\mathrm{C}_{6: 0}\right]$ and $(\gg)\left[\mathrm{N}_{6,6,6,6}\right]\left[\mathrm{C}_{16: 0}\right]$ 
1 Analysing the obtained results, the $50 \%$ conversion mark at $100{ }^{\circ} \mathrm{C}$ is obtained in less than 300 min with

$2\left[\mathrm{~N}_{6,6,6,6,6}\right]\left[\mathrm{C}_{16: 0}\right]$, whereas $\left[\mathrm{N}_{8,8,8,1}\right]\left[\mathrm{C}_{12: 0}\right]$ and $\left[\mathrm{N}_{8,8,8,1}\right]\left[\mathrm{C}_{18: 1}\right]$ needed around 1500 and 2400 min, respectively.

3 On the other hand, the $\left[\mathrm{N}_{8,8,8,1}\right]\left[\mathrm{C}_{6: 0}\right]$ is the most thermally stable FAIL from a long-term thermal stability

4 point of view, reaching the $50 \%$ conversion mark at $100{ }^{\circ} \mathrm{C}$ after more than $3500 \mathrm{~min}$. The thermal stability

5 trend is slightly modified at increasing temperature. This implies that $\left[\mathrm{N}_{6,6,6,6}\right]\left[\mathrm{C}_{16: 0}\right]$ remains the least stable

6 FAIL, reaching the $50 \%$ conversion mark in $22 \mathrm{~min}$ at $150{ }^{\circ} \mathrm{C}$, confirming the cation effect as the most

7 important factor influencing thermal decomposition. However, $\left[\mathrm{N}_{8,8,8,1}\right]\left[\mathrm{C}_{18: 1}\right]$ is now the most thermally

8 stable FAIL at this temperature, needing around $150 \mathrm{~min}$ to reach the mentioned conversion compared to

9102 and $72 \mathrm{~min}$ for $\left[\mathrm{N}_{8,8,8,1}\right][\mathrm{C} 6: 0]$ and $\left[\mathrm{N}_{8,8,8,1}\right]\left[\mathrm{C}_{12: 0}\right]$, respectively. It seems that the temperature increase

10 implies that less effort is necessary to overcome the anion-cation electrostatic interaction, which possibly

11 causes a trend of thermal stability proportional to the chain length of the anion. Finally, results seen in the

12 dynamic and isothermal tests are clearly supported by the isoconversional methodology: the cation effect

13 is very pronounced, the $\left[\mathrm{N}_{6,6,6,6}\right]\left[\mathrm{C}_{16: 0}\right]$ being the FAIL that takes the least time to reach each one of the

14 conversion values shown in Fig. 6.

15 In addition, the comparison between isothermal (experimental) and isoconversional (model free method)

16 values at $T_{0}=200{ }^{\circ} \mathrm{C}$ (Fig. 7) were carried out for some of the FAILs: $\left[\mathrm{N}_{8,8,8,1}\right]\left[\mathrm{C}_{6: 0}\right],\left[\mathrm{N}_{8,8,8,1}\right]\left[\mathrm{C}_{12: 0}\right]$,

$17\left[\mathrm{~N}_{6,6,6,6}\right]\left[\mathrm{C}_{16: 0}\right]$ and $\left[\mathrm{N}_{8,8,8,1}\right]\left[\mathrm{C}_{18: 1}\right]$ under a nitrogen atmosphere. From the results shown in Fig. 7 , it is

18 possible to estimate the time required for a conversion of the studied sample at a given temperature. The

19 best fit between experimental and model results are for the $\left[\mathrm{N}_{8,8,8,1}\right]\left[\mathrm{C}_{12: 0}\right]$ sample. The experimental results

20 at $200{ }^{\circ} \mathrm{C}$ indicate that thermal decomposition reached $30,40,50$ and $60 \%$ conversion at $5,8,11$ and 16

$21 \mathrm{~min}$, respectively, and the calculated values were 3, 5, 7 and $11 \mathrm{~min}$, respectively. Therefore, the results

22 from models showed good agreement. For the other samples, there is also a good level of agreement,

23 especially at lower conversion values, as can be seen in Fig 7. 


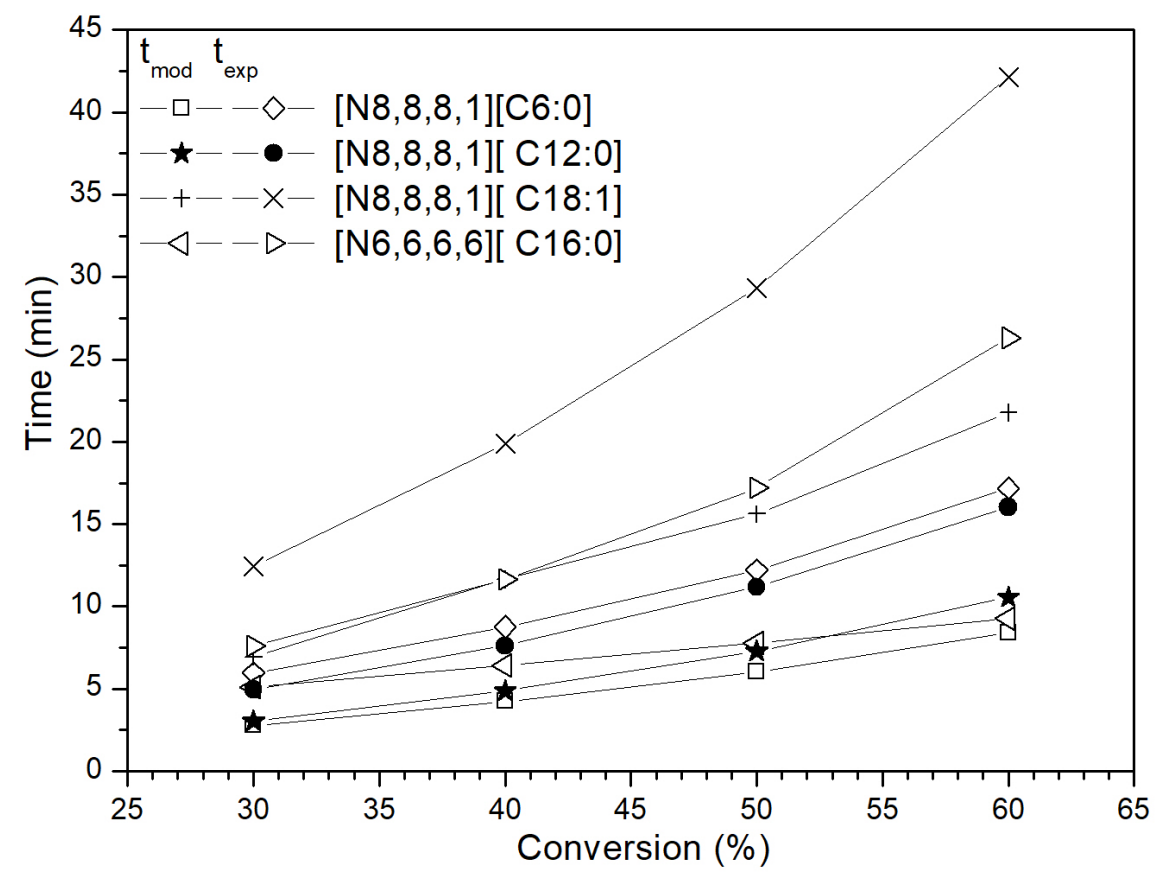

1

Fig. 7 Comparison between experimental and model results for $\left[\mathrm{N}_{8.8 .8 .1}\right]\left[\mathrm{C}_{12: 0}\right],\left[\mathrm{N}_{8,8,8,1}\right]\left[\mathrm{C}_{6: 0}\right]$,

$\left[\mathrm{N}_{6,6,6,6,6}\right]\left[\mathrm{C}_{16: 0}\right]$ and $\left[\mathrm{N}_{8,8,8,1}\right]\left[\mathrm{C}_{18: 1}\right]$ at $T_{0}=200^{\circ} \mathrm{C}$.

4

\section{4. Conclusions}

6 The thermal degradation of eight novel fatty acid anion-based ILs (FAILs): methyltrioctylammonium

7 hexanoate $\left[\mathrm{N}_{8,8,8,1}\right]\left[\mathrm{C}_{6: 0}\right]$, methyltrioctylammonium octanoate $\left[\mathrm{N}_{8,8,8,1}\right]\left[\mathrm{C}_{8: 0}\right]$, tetrahexylammonium

8 octanoate $\left[\mathrm{N}_{6,6,6,6}\right]\left[\mathrm{C}_{8: 0}\right]$, methyltrioctylammonium laurate $\left[\mathrm{N}_{8,8,8,1}\right]\left[\mathrm{C}_{12: 0}\right]$, methyltrioctylammonium

9 palmitate $\left[\mathrm{N}_{8,8,8,1}\right]\left[\mathrm{C}_{16: 0}\right]$, tetrahexylammonium palmitate $\left[\mathrm{N}_{6,6,6,6}\right]\left[\mathrm{C}_{16: 0}\right]$, methyltrioctylammonium stearate

$10\left[\mathrm{~N}_{8,8,8,1}\right]\left[\mathrm{C}_{18: 0}\right]$ and methyltrioctylammonium oleate $\left[\mathrm{N}_{8,8,8,1}\right]\left[\mathrm{C}_{18: 1}\right]$, was studied under a nitrogen

11 atmosphere using both dynamic and isothermal approaches. The main conclusions extracted from the

12 obtained results are the following:

13 - The thermal stability of these FAILs is controlled by both the cation and anion, the cation effect 14 being more important since samples including the $\left[\mathrm{N}_{6,6,6,6}\right]^{+}$cation were the most thermally unstable. 
- Most samples have a decomposition onset temperature $\left(T_{\text {onset }}\right)$ below $200{ }^{\circ} \mathrm{C}$ and the $\left[\mathrm{N}_{8,8,8,1}\right]\left[\mathrm{C}_{16: 0}\right],\left[\mathrm{N}_{8,8,8,1}\right]\left[\mathrm{C}_{18: 0}\right]$ and $\left[\mathrm{N}_{8,8,8,1}\right]\left[\mathrm{C}_{18: 1}\right]$ had the higher $T_{\text {onset }}$ values, probably due to the longer alkyl chain length in the anion.

- All the FAILs exhibited lower thermal stability under a nitrogen atmosphere than commercially available ILs tested before in lubrication studies, especially those containing the $\left[\mathrm{NTf}_{2}\right]^{-}$anion.

- FAILs in isothermal experiments showed appreciable decomposition at temperatures significantly lower than the values indicated by the $T_{\text {onset }}$ calculated from dynamic TGA.

- The $\left[\mathrm{N}_{8,8,8,1}\right]\left[\mathrm{C}_{6: 0}\right]$ and $\left[\mathrm{N}_{8,8,8,1}\right]\left[\mathrm{C}_{8: 0}\right]$ showed the highest long-term thermal stability, probably related to their stronger anion-cation electrostatic interaction. This led to the multi-step thermal decomposition mechanism observed in the DTG results.

- The experimental isothermal results for the $\left[\mathrm{N}_{8,8,8,1}\right]\left[\mathrm{C}_{12: 0}\right]$ sample agree with the model-free methods.

\section{Nomenclature}

\begin{tabular}{|c|c|c|}
\hline$A$ & $\left(\mathrm{~m}^{3} \cdot \mathrm{mol}^{-1}\right)^{\mathrm{n}-1} \mathrm{~s}^{-1}$ & Pre-exponential factor \\
\hline $\boldsymbol{E}_{\boldsymbol{a}}$ & $\mathrm{kJ} / \mathrm{mol}$ & Activation Energy \\
\hline$M$ & mol & Molar mass of the ionic liquid \\
\hline$f(\alpha), g(\alpha)$ & - & Reaction models \\
\hline$k(T)$ & $\mathrm{J} / \mathrm{K}$ & Temperature dependent constant \\
\hline $\boldsymbol{R}$ & $\mathrm{J} / \mathrm{K} / \mathrm{mol}$ & Gas constant \\
\hline$t$ & $\mathrm{~s}$ & Time \\
\hline$T$ & ${ }^{\circ} \mathrm{C}$ & Temperature \\
\hline$T_{\text {onset }}$ & ${ }^{\circ} \mathrm{C}$ & Onset Temperature \\
\hline$T_{\text {endset }}$ & ${ }^{\circ} \mathrm{C}$ & Endset Temperature \\
\hline $\boldsymbol{T}_{10 \%}$ & ${ }^{\circ} \mathrm{C}$ & Temperature at $10 \%$ of mass loss \\
\hline$T_{50 \%}$ & ${ }^{\circ} \mathrm{C}$ & Temperature at $50 \%$ of mass loss \\
\hline$T_{0}$ & ${ }^{\circ} \mathrm{C}$ & Arbitrary temperature to a given extent of reaction, $\alpha$ \\
\hline$m_{i}$ & $\mathrm{~kg}$ & Initial mass \\
\hline$m_{e}$ & $\mathrm{~kg}$ & Mass at the end of the experiment \\
\hline $\boldsymbol{m}_{t}$ & $\mathrm{~kg}$ & Mass at time, $\mathrm{t}$ \\
\hline
\end{tabular}




$\begin{array}{lll}\boldsymbol{W}_{\text {total loss }} & \% & \text { Total weight loss } \\ \boldsymbol{W}_{\text {onset }} & \% & \text { Weight loss at Tonset } \\ \boldsymbol{\alpha} & - & \text { Extent of reaction } \\ \boldsymbol{\beta} & \mathrm{K} \cdot \mathrm{min}^{-1} & \text { Heating rate }\end{array}$

\section{Acknowledgements}

4 The authors thank the Spanish Ministry of Economy and Competitiveness and the Foundation for the 5 Promotion of Applied Scientific Research and Technology in Asturias (FICYT) for supporting this work 6 under the framework of the research projects FAILs_LUBEs (DPI2016-79690-R) and LuSuTec 7 (IDI/2018/000131), respectively. The Unit of Thermal Tests and Elemental Analysis of the Scientific8 Technical Services at the University of Oviedo is also acknowledged.

\section{References}

11 [1] P. Walden, Molecular weights and electrical conductivity of several fused salts, Bulletin of the Imperial Academy of Sciences (St. Petersburg) 8 (1914) 405-422.

13 [2] P. Wasserscheid, T. Welton. Ionic Liquids in Synthesis. Wiley- VCH Verlag GmbH \& Co. KGaA, (2002).

15 [3] M. Freemantle. An Introduction to Ionic Liquids. Royal Society of Chemistry, 2009. ISBN 978-1$84755-161-0$

17 [4] F. Guo, S. Zhang, J. Wang, B. Teng, T. Zhang, M. Fan. Synthesis and applications of ionic liquids in clean energy and environment: a review, Curr. Org. Chem. 19(5) (2015) 455-468. https://doi.org/10.2174/1385272819666150114235649

[5] F. Zhou, Y. Liang, W. Liu. Ionic liquid lubricants: designed chemistry for engineering applications, Chem. Soc. Rev. 38 (2009) 2590-2599. https://doi.org/10.1039/ b817899m

[6] A. Berthod, M.J. Ruiz-Ángel, S. Carda-Broc. Recent advances on ionic liquid uses in separation techniques. J. Chromatogr. A 1559 (2018) 2-16. https://doi:10.1016/j.chroma.2017.09.044

[7] H. Liu, H. Yu. Ionic liquids for electrochemical energy storage devices applications. J. Mater. Sci. 
1 [8] Z. Ullah, A.S. Khan, N. Muhammad, R. Ullah, A.S. Alqahtani, S.N. Shah, O.B.Ghanem, M.A. Bustam, Z. Man. A review on ionic liquids as perspective catalysts in transesterification of different feedstock oil into biodiesel. J Mol Liq 2018;266:673-86. https://doi:10.1016/j.molliq.2018.06.024

[9] L. Zhang, B. Zhao, Y. Zhang, Q. Zhao, H. Chu, Z. Liang. Advances of ionic liquids-based methods for protein analysis. TrAC Trends Anal. Chem. $108 \quad$ (2018) 239-246. https://doi:10.1016/j.trac.2018.09.008

[10] F. Javed, F. Ullah, M.R. Zakaria, H.M. Akil. An approach to classification and hi-tech applications of room-temperature ionic liquids (RTILs): A review. J. Mol. Liq. 271 (2018) 403-420. https://doi:10.1016/j.molliq.2018.09.005

[11] M. Aghaie, N. Rezaei, S. Zendehboudi S. A systematic review on $\mathrm{CO}_{2}$ capture with ionic liquids: Current status and future prospects. Renew. Sustain. Energy Rev. 96 (2018) 502-525. https://doi:10.1016/j.rser.2018.07.004.

[12] L.Y. Wang, Q.J. Guo, M.S. Lee. Recent advances in metal extraction improvement: Mixture systems consisting of ionic liquid and molecular extractant. Sep. Purif. Technol. 210 (2019). 292-303. https://doi:10.1016/j.seppur.2018.08.016

[13] S.A.S. Amiril, E.A. Rahim, S. Syahrullai. A review on ionic liquids as sustainable lubricants in manufacturing and engineering: Recent research, performance, and applications. J. Clean Prod. 168 (2017) 1571-1589. https://doi:10.1016/j.jclepro.2017.03.197

[14] Y. Zhou, J. Qu. Ionic liquids as lubricant additives - a Review. ACS Appl. Mater. Interfaces 9(4) (2016) 3209-3222. https://doi:10.1021/acsami.6b12489

[15] H. Xiao. Ionic liquid lubricants: Basics and applications. Tribol. Trans. 60 (2017) 20-30. https://doi:10.1080/10402004.2016.1142629

[16] C. Ye, W. Liu, Y. Chen, L. Yu. Room-temperature ionic liquids: A novel versatile lubricant, Chem. Commun. 21 (2001) 2244-2245. https://doi:10.1039/B106935G

[17] M.D. Bermúdez, A.E. Jiménez, J. Sanes, F.J. Carrión, Ionic liquids as advanced lubricant fluids, Molecules. 14 (2009) 2888-2908. doi:10.3390/molecules14082888.

[18] I. Minami. Ionic liquids in tribology, Molecules. $14 \quad$ (2009) 2286-2305. https://doi:10.3390/molecules 14062286

[19] J. Qu, P.J. Blau, S. Dai, H. Luo, H.M. Meyer. Ionic liquids as novel lubricants and additives for diesel engine applications, Tribol. Lett. 35 (2009) 181-189. https://doi:10.1007/s11249-009-9447-1 
1 [20] M. Palacio, B. Bhushan. A review of ionic liquids for green molecular lubrication in nanotechnology, Tribol. Lett. 40 (2010) 247-268. https://doi:10.1007/s11249-010-9671-8

3 [21] A.H. Battez, R. González, J.L. Viesca, D. Blanco, E. Asedegbega, A. Osorio. Tribological behaviour of two imidazolium ionic liquids as lubricant additives for steel/steel contacts, Wear 266 (2009) 12241228. https://doi:10.1016/j.wear.2009.03.043

[22] W. Liu, C. Ye, Q. Gong, H. Wang, P. Wang. Tribological performance of room-temperature ionic liquids as lubricant, Tribol. Lett. 13 (2002) 81-85. https://doi:10.1023/A:1020148514877.

[23] A.E. Jiménez, M.D. Bermúdez. Imidazolium ionic liquids as additives of the synthetic ester propylene glycol dioleate in aluminium-steel lubrication, Wear 265 (2008) 787-798. https://doi:10.1016/j.wear.2008.01.009

[24] M.G. Freire, C.M.S.S. Neves, I.M. Marrucho, J.A P. Coutinho, A.M. Fernandes. Hydrolysis of tetrafluoroborate and hexafluorophosphate counter ions in imidazolium-based ionic liquids, J. Phys. Chem. A. 114 (2009) 3744-3749. https://doi:10.1021/jp903292n

[25] K. Marczewska-boczkowska, M. Kosmulski. The Effect of chloride and water on the corrosion of copper in 1-Butyl-3-Methylimidazolium Tetraflouroborate. Mater. Manuf. Process. 24 (2009) 11731179. https://doi.org/10.1080/10426910902976146

[26] K. Marczewska-Boczkowska, M. Kosmulski. 2-Mercaptobenzothiazole as a corrosion inhibitor in low temperature ionic liquids. Trends in Colloid and Interface Science XXIV (2011) 165-171. https://doi.org/10.1007/978-3-642-19038-4_30

[27] B. Dilasari, Y. Jung, J. Sohn, S. Kim, K. Kwon. Review on corrosion behavior of metallic materials in room temperature ionic liquids, International Journal of Electrochemical Science 11(2) (2016) $1482-1495$

[28] L. Pisarova, C. Gabler, N. Dörr, E. Pittenauer, G. Allmaier. Thermo-oxidative stability and corrosion properties of ammonium based ionic liquids. Tribol. Int. 46 (2012) 73-83. https://doi.org/10.1016/j.triboint.2011.03.014

[29] J.L. Viesca, M. Anand, D. Blanco, A. Fernández-González, A. García, M. Hadfield. Tribological behaviour of PVD coatings lubricated with a FAP- anion-based ionic liquid used as an additive, lubricants 4(1) (2016) 8. https://doi:10.3390/lubricants4010008 
1 [30] J.L. Viesca, A. García, A. Hernández Battez, R. González, R. Monge, A. Fernández-González, M. Hadfield. FAP- anion ionic liquids used in the lubrication of a steel-steel contact, Tribol. Lett. 52 (2013) 431-437. https://doi:10.1007/s11249-013-0226-7

[31] A. Hernández Battez, R. González, J.L. Viesca, A. Fernández-González, M. Hadfield. Lubrication of PVD coatings with ethyl-dimethyl-2-methoxyethylammonium tris(pentafluoroethyl) trifluorophosphate, Tribol. Int. 58 (2013) 71-78. https://doi:10.1016/j.triboint.2012.10.001

[32] R. González, A. Hernández Battez, D. Blanco, J.L. Viesca, A. Fernández-González. Lubrication of TiN, CrN and DLC PVD coatings with 1-butyl-1- methylpyrrolidinium tris(pentafluoroethyl)trifluorophosphate, Tribol. Lett. $40 \quad$ (2010) 269-277. https:// doi:10.1007/s11249-010-9674-5

[33] R. González, A.H. Battez, J.L. Viesca, A. Higuera-Garrido, A. Fernández-González. Lubrication of DLC coatings with two tris(pentafluoroethyl)trifluorophosphate anion-based ionic liquids, Tribol. Trans. 56 (2013) 887-895. https://doi:10.1080/10402004.2013.810319

[34] D. Blanco, R. González, A. Hernández Battez, J.L. Viesca, A. Fernández-Gonzlez. Use of ethyldimethyl-2-methoxyethylammonium tris(pentafluoroethyl) trifluorophosphate as base oil additive in the lubrication of TiN PVD coating, Tribol. Int. 44 (2011) 645-650. https://doi:10.1016/j.triboint.2011.01.004

[35] I. Minami, M. Kita, T. Kubo, H. Nanao, S. Mori. The tribological properties of ionic liquids composed of trifluorotris(pentafluoroethyl) phosphate as a hydrophobic anion, Tribol. Lett. 30 (2008) 215-223. https://doi:10.1007/s11249-008-9329-y

[36] A. García, R. González, A. Hernández Battez, J.L. Viesca, R. Monge, A. Fernández-González, M. Hadfield. Ionic liquids as a neat lubricant applied to steel-steel contacts, Tribol. Int. 72 (2014) 42-50. https://doi:10.1016/j.triboint.2013.12.007

[37] D. Blanco, A. H. Battez, J.L. Viesca, R. González, A. Fernández-González. Lubrication of CrN coating with ethyl-dimethyl-2-methoxyethylammonium tris(pentafluoroethyl)trifluorophosphate ionic liquid as additive to PAO 6, Tribol. Lett. 41 (2011) 295-302. https://doi:10.1007/s11249-010-9714-1

[38] A.E. Somers, S.M. Biddulph, P.C. Howlett, J. Sun, D.R. MacFarlane, M. Forsyth. A comparison of phosphorus and fluorine containing IL lubricants for steel on aluminium, Phys. Chem. Chem. Phys. 14 (2012) 8224. https://doi:10.1039/c2cp40736a 
1 [39] B.A. Kheireddin, W. Lu, I.C. Chen, M. Akbulut. Inorganic nanoparticle-based ionic liquid lubricants, Wear. 303 (2013) 185-190. https://doi:10.1016/j.wear.2013.03.004

[40] A.E. Somers, P.C. Howlett, J. Sun, D.R. MacFarlane, M. Forsyth. Transition in wear performance for ionic liquid lubricants under increasing load, Tribol. Lett. 40 (2010) 279-284. https://doi:10.1007/s11249-010-9695-0

[41] T. Murakami, K. Kaneda, M. Nakano, A. Korenaga, H. Mano, S. Sasaki. Tribological properties of Fe7Mo6-based alloy under two ionic liquid lubrications, Tribol. Int. 41 (2008) 1083-1089. https://doi:10.1016/j.triboint.2008.02.017

[42] P. Bandeira, J. Monteiro, A.M. Baptista, F.D. Magalhães. Tribological performance of PTFE-based coating modified with microencapsulated [HMIM][NTf 2 ionic liquid, Tribol. Lett. 59 (2015) 13. https://doi:10.1007/s11249-015-0545-y

[43] C. Gabler, N. Dörr, G. Allmaier. Influence of cationic moieties on the tribolayer constitution shown for bis(trifluoromethylsulfonyl)imide based ionic liquids studied by X-ray photoelectron spectroscopy, Tribol. Int. 80 (2014) 90-97. https://doi:10.1016/j.triboint.2014.06.018

[44] R. Monge, R. González, A. Hernández Battez, A. Fernández-González, J.L. Viesca, A. García, M. Hadfield. Ionic liquids as an additive in fully formulated wind turbine gearbox oils, Wear. 328-329 (2015) 50-63. https://doi:10.1016/j.wear.2015.01.041

[45] A.E. Somers, P. Howlett, D. MacFarlane, M. Forsyth. A review of ionic liquid lubricants, Lubricants. 1 (2013) 3-21. https://doi:10.3390/lubricants1010003

[46] M. Smiglak, A. Metlen, R.D. Rogers. Second evolution of ionic liquids: From solvents and separations to advanced materials - energetic, Acc. Chem. Res. 40(11) (2007) 1182-1192. https://doi.org/10.1021/ar7001304

[47] S.P.F. Costa, A.M.O. Azevedo, P.CA.G. Pinto, M.L.M.F.S. Saraiva. Environmental impact of ionic liquids: recent advances in (eco)toxicology and (bio)degradability, Chem. Sus. Chem. 10(10) (2017) 2321-2347. https://doi.org/10.1002/cssc.201700261

[48] P. Nagendramma, S. Kaul, Development of ecofriendly/biodegradable lubricants: An overview, Renew. Sustain. Energy Rev. 16 (2012) 764-774. https://doi.org/10.1016/j.rser.2011.09.002

[49] C.J. Reeves, S. Garvey, P.L. Menezes, M. Dietz, T.C. Jen, M.R. Lovell. Tribological performance of environmentally friendly ionic liquid lubricants, Am. Soc. Mech. Eng. Tribol. Div. TRIB. (2012) 355357. https://doi.org/10.1115/IJTC2012-61180 
1 [50] A. Wang, L. Chen, D. Jiang, H. Zeng, Z. Yan. Vegetable oil-based ionic liquid microemulsion biolubricants: effect of integrated surfactants, Ind. Crops Prod. 62 (2014) 515-521. https://doi.org/10.1016/j.indcrop.2014.09.031

[51] A.Z. Syahir, N.W.M. Zulkifli, H.H. Masjuki, M.A. Kalam, A. Alabdulkarem, M. Gulzar, L.S. Khuong, M.H. Harith. A review on bio-based lubricants and their applications, J. Clean. Prod. 168 (2017) 9971016. https://doi.org/10.1016/j.jclepro.2017.09.106

[52] N. Adawiyah, S. Hawatulaila, A. Aini, A. Vijaya, M. Ibrahim, M. Moniruzzaman. Synthesis, characterization, ecotoxicity and biodegradability evaluations of novel biocompatible surface active lauroyl sarcosinate ionic liquids, Chemosphere, $229 \quad$ (2019) 349-357. https://doi.org/10.1016/j.chemosphere.2019.05.026

[53] D. Parmentier, S.J. Metz, M.C. Kroon. Tetraalkylammonium oleate and linoleate based ionic liquids: promising extractants for metal salts, Green Chem. 15(1) (2013) 205-209. https://doi.org/10.1039/C2GC36458A

[54] M.A.A. Rocha, A. Van Den Bruinhorst, W. Schröer, B. Rathke, M.C. Kroon. Physicochemical properties of fatty acid based ionic liquids, J. Chem. Thermodyn. (2016). https://doi.org/10.1016/j.jct.2016.04.021

[55] R. Gusain, S. Dhingra, O.P. Khatri. Fatty-acid-constituted halogen-free ionic liquids as renewable, environmentally friendly, and high-performance lubricant additives, Ind. Eng. Chem. Res. 55(4) (2016) 856-865. https://doi.org/10.1021/acs.iecr.5b03347

[56] R. Gusain O.P. Khatri. Fatty acid ionic liquids as environmentally friendly lubricants for low friction and wear, RSC Adv. 6(5) (2016) 3462-3469. https://doi.org/10.1039/C5RA25001C

[57] A. Mezzetta, L. Guazzelli, M. Seggiani, C.S. Pomelli, M. Puccini, C. Chiappe. A general environmentally friendly access to long chain fatty acid ionic liquids (LCFA-ILs), Green Chem. 19 (2017) 3103-3111. https://doi.org/10.1039/c7gc00830a

[58] M. Fan, L. Ma, C. Zhang, Z. Wang, J. Ruan, M. Han, Y. Ren, C. Zhang, D. Yang, F. Zhou, W. Liu. Biobased green lubricants: physicochemical, tribological and toxicological properties of fatty acid ionic liquids, Trib. Trans. 61(2) (2017) 195-206. https://doi.org/10.1080/10402004.2017.1290856

[59] P.K. Khatri, M.S. Aathira, G.D. Thakre, S.L. Jain. Synthesis and tribological behavior of fatty acid constituted tetramethylguanidinium (TMG) ionic liquids for a steel/steel contact, Mater. Sc. Eng. C 91 (2018) 208-217. https://doi.org/10.1016/j.msec.2018.05.038 
1 [60] G. Zheng, T. Ding, Y. Huang, L. Zheng, T. Ren. Fatty acid based phosphite ionic liquids as multifunctional lubricant additives in mineral oil and refined vegetable oil, Tribol. Int. 123 (2018) 316-324. https://doi.org/10.1016/J.TRIBOINT.2018.03.028

[61] D. Blanco, N. Rivera, P. Oulego, M. Díaz, R. González, A.H. Battez. Novel fatty acid anion-based ionic liquids : Contact angle, surface tension, polarity fraction and spreading parameter, J. Mol. Liq. 288 (2019) 110995. https://doi.org/10.1016/j.molliq.2019.110995

[62] N. Rivera, D. Blanco, J.L. Viesca, A. Fernández-González, R. González, A.H. Battez. Tribological performance of three fatty acid anion-based ionic liquids (FAILs) used as lubricant additive. J. of Mol. Liq. 296 (2019) 111881. https://doi.org/10.1016/j.molliq.2019.111881

[63] A. Khan, R. Gusain, M. Sahai, O.P. Khatri. Fatty acids-derived protic ionic liquids as lubricant 111444. https://doi.org/10.1016/J.MOLLIQ.2019.111444

[64] N. Rivera, A. García, A. Fernández-González, D. Blanco, R. González, A.H. Battez. Tribological behavior of three fatty acid ionic liquids in the lubrication of different material pairs. J. Mol. Liq. 296 (2019) 111881. https://doi.org/10.1016/j.molliq.2019.111858

[65] K. Ali, R. Moshikur, R. Wakabayashi, Y. Tahara. Synthesis and characterization of choline - fattyacid-based ionic liquids: A new biocompatible surfactant. Journal of Colloid and Interface Science, 551 (2019) 72-80. https://doi.org/10.1016/j.jcis.2019.04.095

[66] P. Oulego, J. Faes, R. González, J.L. Viesca, D. Blanco, A.H. Battez. Relationships between the physical properties and biodegradability and bacteria toxicity of fatty acid-based ionic liquids. J. Mol. Liq., 292 (2019) 111451. https://doi.org/10.1016/j.molliq.2019.111451

[67] T. Gundolf, N. Weyhing-Zerrer, J. Sommer, R. Kalb, D. Schoder, P. Rossmanith, P. Mester. Biological Impact of Ionic Liquids Based on Sustainable Fatty Acid Anions Examined with a Tripartite Test System, ACS Sustainable Chemistry and Engineering, 7(19) (2019) 15865-15873. https://doi.org/10.1021/acssuschemeng.8b06201

[68] R. Gusain, A. Khan, O.P. Khatri. Fatty acid-derived ionic liquids as renewable lubricant additives: Effect of chain length and unsaturation, Journal of Molecular Liquids, 301 (2020) 112322. https://doi.org/10.1016/j.molliq.2019.112322

[69] M. Sernaglia, D. Blanco, A. Hernández Battez, J.L. Viesca, R. González, M. Bartolomé. Two fatty acid anion-based ionic liquids - part I: Physicochemical properties and tribological behavior as neat 
$\begin{array}{llll}\text { lubricants. Journal of } & \text { Molecular Liquids } & \text { (2020) }\end{array}$ https://doi.org/10.1016/j.molliq.2020.112827

3 [70] M. Sernaglia, D. Blanco, A. Hernández Battez, R. González, A. Fernández-González, A., \& M. Bartolomé. Two fatty acid anion-based ionic liquids - part II: Effectiveness as an additive to a polyol ester. Journal of Molecular Liquids 310 (2020) 113158. https://doi.org/10.1016/j.molliq.2020.113158

[71] A. Seeberger, A.-K. Andresen, A. Jess. Prediction of long-term stability of ionic liquids at elevated temperatures by means of non-isothermal thermogravimetrical analysis., Phys. Chem. Chem. Phys. 11 (2009) 9375-9381. https://doi:10.1039/b909624h

[72] A. Hernández Battez, M. Bartolomé, D. Blanco, J.L. Viesca, A. Fernández-González, R. González. Phosphonium cation-based ionic liquids as neat lubricants: Physicochemical and tribological

[73] C. Maton, N. De Vos, C.V. Stevens. Ionic liquid thermal stabilities: Decomposition mechanisms and analysis tools. Chem. Soc. Rev. 42 (2013) 5963-5977. https://doi:10.1039/C3CS60071H

[74] N. Meine, F. Benedito, R. Rinaldi. Thermal stability of ionic liquids assessed by potentiometric titration. Green Chem. 12 (2010) 1711-1714. https://doi:10.1039/C0GC00091D

[75] H.L. Ngo, K. LeCompte, L. Hargens, A.B. McEwen. Thermal properties of imidazolium ionic liquids, Thermochim. Acta. 357-358 (2000) 97-102. https://doi:10.1016/S0040-6031(00)00373-7

[76] Y.U. Paulechka, D.H. Zaitsau, G.J. Kabo, A.A. Strechan. Vapor pressure and thermal stability of ionic liquid 1-butyl-3- methylimidazolium Bis(trifluoromethylsulfonyl)amide, Thermochim. Acta. 439 (2005) 158-160. https://doi:10.1016/j.tca.2005.08.035

[77] M. Kosmulski, J. Gustafsson, J.B. Rosenholm. Thermal stability of low temperature ionic liquids revisited, Thermochim. Acta. 412 (2004) 47-53. https://doi:10.1016/j.tca.2003.08.022.

[78] T.J. Wooster, K.M. Johanson, K.J. Fraser, D.R. MacFarlane, J.L. Scott. Thermal degradation of cyano containing ionic liquids. Green Chem. 8 (2006) 691-696. https://doi:10.1039/B606395K

[79] R.E. Del Sesto, T.M. McCleskey, C. Macomber, K.C. Ott, A.T. Koppisch, G.A. Baker, A.K. Burrell. Limited thermal stability of imidazolium and pyrrolidinium ionic liquids, Thermochim. Acta. 491 (2009) 118-120. https://doi:10.1016/j.tca.2009.02.023

[80] A. Efimova, L. Pfützner, P. Schmidt. Thermal stability and decomposition mechanism of 1-ethyl-3methylimidazolium halides, Thermochim. Acta. $604 \quad$ (2015) 129-136. https://doi.org/10.1016/j.tca.2015.02.001 
[81] M. Krannich, F. Heym, A. Jess. Characterization of six hygroscopic ionic liquids with regard to their suitability for gas dehydration: density, viscosity, thermal and oxidative stability, vapor pressure, diffusion coefficient, and activity coefficient of water, J. Chem. Eng. Data. 61 (2016) 1162-1176. https://doi.org/10.1021/acs.jced.5b00806

[82] F. Heym, B.J.M. Etzold, C. Kern, A. Jess. An improved method to measure the rate of vaporisation and thermal decomposition of high boiling organic and ionic liquids by thermogravimetrical analysis. Phys Chem Chem Phys 12 (2010) 12089-100. https://doi:10.1039/C0CP00097C.

[83] F. Heym, W. Korth, J. Thiessen, C. Kern, A. Jess. Evaporation and decomposition behavior of pure and supported ionic liquids under thermal, Chemie Ing. Tech. 87 (2015) 791-802. https://doi.org/10.1002/cite.201400139

[84] F. Heym, W. Korth, B.J.M. Etzold, C. Kern, A. Jess. Determination of vapor pressure and thermal decomposition using thermogravimetrical analysis, Thermochim. Acta. 622 (2015) 9-17. https://doi.org/10.1016/j.tca.2015.03.020

[85] F. Heym, C. Kern, J. Thiessen, A. Jess. Transport phenomena, evaporation and thermal stability of ionic liquids. In: R. Fehrmann, A. Riisager, M. Haumann (eds.): Supported Ionic Liquids Fundamentals and Applications. Wiley VCH (2014) 105-143 (ISBN: 9783527324293)

[86] F. Heym, B.J.M. Etzold, C. Kern, A. Jess. Analysis of evaporation and thermal decomposition of ionic liquids by thermogravimetrical analysis at ambient pressure and high vacuum, Green Chem. 13 (2011) 1453-1466. https://doi: 10.1039/C0GC00876A

[87] W.H. Awad, J.W. Gilman, M. Nyden, R.H. Harris Jr, T.E. Sutto, J. Callahan, P.C. Trulove, H.C. DeLong, D.M. Fox. Thermal degradation studies of alkyl-imidazolium salts and their application in nanocomposites, Thermochim. Acta 409 (2004) 3-11. https://doi: 10.1016/S0040-6031(03)00334-

[88] Y. Cao, T. Mu. Comprehensive investigation on the thermal stability of 66 ionic liquids by thermogravimetric analysis, Ind. Eng. Chem. Res. 53 (2014) 8651-8664. https://doi: $10.1021 /$ ie 5009597

[89] M. Scheuermeyer, M. Kusche, F. Agel, P. Schreiber, F. Maier, H.-P. Steinruck, J.H. Davis, F. Heym, A. Jess, P. Wasserscheid. Thermally stable bis(trifluoromethylslfonyl)imide salts and their mixtures, New J. Chem. 40 (2016) 7157-7161. https://doi: 10.1039/C6NJ00579

[90] J.G. Huddleston, A.E. Visser, W.M. Reichert, H.D. Willauer, G.A. Broker, R.D. Rogers. Characterization and comparison of hydrophilic and hydrophobic room temperature ionic liquids 
incorporating the imidazolium cation, Green Chemistry 3 (2001) 156-164. https://doi.org/10.1039/B103275P

[91] J.M. Crosthwaite, M.J. Muldoon, J.K. Dixon, J.L. Anderson, J.F. Brennecke. Phase transition and decomposition temperatures, heat capacities and viscosities of pyridinium ionic liquids, J. Chem. Thermodyn. 37 (2005) 559-568. https://doi:10.1016/j.jct.2005.03.013.

[92] M. Montanino, M. Carewska, F. Alessandrini, S. Passerini, G.B. Appetecchi. The role of the cation

[99] A.S. Khan, Z. Man, M.A. Bustam, C.F. Kait, Z. Ullah, A. Nasrullah, M.I. Khan, G. Gonfa, P. Ahmad, 
biomass. Journal of Molecular Liquids $223 \quad$ (2016) 754-762. https://doi: 10.1016/j.molliq.2016.09.012.

[100] M. Rezaeian, M. Izadyar. Theoretical investigation of the thermal decomposition of imidazolium ionic liquids with different halides ions. J. Mol. Liq. 224 (2016) 460-465. https://doi.org/10.1016/j.molliq.2016.10.028

[101] L. Rui, Y. Meirong, X. Xiaopeng. Thermal stability and thermal decomposition kinetics of 1-butyl3-methylimidazolium dicyanamide. Chin. J. Chem. Eng. $18 \quad$ (2010) 736-741. https://doi:10.1016/S1004-9541(09)60122-1.

9 [102] J. Salgado, M. Villanueva, J.J. Parajó, J. Fernández. Long-term thermal stability of five imidazolium ionic liquids, J. Chem. Thermodyn. $65 \quad$ (2013) 184-190. https://doi:10.1016/j.jct.2013.05.049.

[103] D.M. Fox, J.W. Gilman, H.C. De Long, P.C. Trulove. TGA decomposition kinetics of 1-butyl2,3-dimethylimidazolium tetrafluoroborate and the thermal effects of contaminants, J. Chem. 4 Thermodyn. 37 (2005) 900-905. https://doi:10.1016/j.jct.2005.04.020.

[104] D. Blanco, M. Bartolomé, B. Ramajo, J.L. Viesca, R. González. Isoconversional kinetic analysis 6 applied to five phosphonium cation-based ionic liquids, Thermochim. Acta. 648 (2017) 62-74. https://doi:10.1016/j.tca.2016.12.014.

8 [105] M. Götz, R. Reimert, S. Bajohr, H. Schnetzer, J. Wimberg, T.J.S. Schubert. Long-term thermal 9 stability of selected ionic liquids in nitrogen and hydrogen atmosphere, Thermochim. Acta. 600 (2015) 82-88. https://doi:10.1016/j.tca.2014.11.005.

1 [106] A.H. Battez, N. Rivera, D. Blanco, P. Oulego, J.L. Viesca, R. González. Physicochemical, traction 22 and tribofilm formation properties of three octanoate-, laurate- and palmitate-anion based ionic 3 liquids, J. Mol. Liq. 284 (2019) 639-646. https://doi:10.1016/j.molliq.2019.04.050.

4 [107] S. Vyazovkin, A.K. Burnham, L. Favergeon, N. Koga, E. Moukhina, L.A. Pérez-Maqueda \& N. 5 Sbirrazzuoli. ICTAC Kinetics Committee recommendations for analysis of multi-step kinetics. 6 Thermochimica Acta, 689 (2020) 178597. https://doi.org/10.1016/j.tca.2020.178597.

7 [108] B. Ramajo-Escalera, A. Espina, J.R. García, J.H. Sosa-Arnao, S.A. Nebra. Model-free kinetics 8 applied to sugarcane bagasse combustion, Thermochim. Acta. 448 (2006) 111-116. 9 https://doi:10.1016/j.tca.2006.07.001. 
1 [109] D. Blanco, P. Oulego, D. Ramos, B. Fernández \& J.M. Cuetos. Model-free kinetics applied to evaluate the long-term thermal stability of three $\left[\mathrm{NTf}_{2}\right]$ anion-based ionic liquids. Thermochimica Acta, 656 (2017) 70-84. https://doi.org/10.1016/j.tca.2017.08.002.

[110] P. Rajeshwari. Kinetic analysis of the non-isothermal degradation of high-density polyethylene filled with multi-wall carbon nanotubes. Journal of Thermal Analysis and Calorimetry 123(2) (2016) 15231544. https://doi: 10.1007/s10973-015-5021-2.

[111] K. Zhang, J. Hong, G. Cao, D. Zhan, Y. Tao, C. Cong. The kinetics of thermal dehydration of copper(II) acetate monohydrate in air, Thermochim. Acta. 437 (2005) 145-149. https://doi:10.1016/j.tca.2005.06.038.

[112] S. Vyazovkin, C.A. Wight, Kinetics in solids, Annu. Rev. Phys. Chem. 48 (1997) 125-149, http://dx.doi.org/10.1146/annurev.physchem.48.1.125.

[113] Z. Xue, Y. Zhang, X.Q. Zhou, Y. Cao, T. Mu, Thermal stabilities and decomposition mechanism of amino- and hydroxyl-functionalized ionic liquids, Thermochim. Acta 578 (2014) 59-67, http://dx.doi.org/10.1016/j.tca. 2013.12.005.

[114] J.M. Crosthwaite, M.J. Muldoon, J.K. Dixon, J.L. Anderson, J.F. Brennecke, Phase transition and decomposition temperatures, heat capacities and viscosities of pyridinium ionic liquids, J. Chem. Thermodyn. 37 (2005) 559-568, http://dx. doi.org/10.1016/j.jct.2005.03.013.

[115] A.N. Masri, M.I. ;atulib, W.Z.N. Yahya, N.F. Aminuddin, J-M Leveque, Thermokinetics of SO3-Hfunctionlized dicationic ionic liquids: Effectt of anions, Mat Sc. \& Eng 458 (2018) 012072.

[116] W.D. Liang, H.F. Li, G.J. Gou. A.Q. Wang. Estudy of Preparation and Thermal Stability of CyanoFunctionalized Imidazolium Type Ionic Liquids, Asian J. Chem 25(9) (2003) 4779-4782.

[117] S. Bourbigot, J.W. Gilman, C.A. Wilkie. Kinetic analysis of the thermal degradation of polystyrenemontmorillonite nanocomposite, Polym. Degrad. Stab. $84 \quad$ (2004) 483-492. https://doi:10.1016/j.polymdegradstab.2004.01.006.

[118] M.V. Kok, E. Topa. Thermal characterization and model-free kinetics of biodiesel sample, J. Therm. Anal. Calorim. 122 (2015) 955-961. https://doi:10.1007/s10973-015-4814-7.

[119] S. Vyazovkin. Isoconversional Kinetics of Thermally Stimulated Processes. Ed. Springer. 2015 
1 [120] T. Wanjun, L. Yuwen, Y. Xil, W. Zhiyong, W. Cunxin, Approximate formulae for calculation of the

$2 \quad$ integral $\int_{0}^{T} T^{m} e^{-E_{\alpha} / R T} d T$, J. Therm. Anal. Calorim. 81 (2005) 347-349. doi:10.1007/s10973-005-

$3 \quad 0790-7$.

4 [121] L. Rui, Y. Meirong, X. Xiaopeng, Thermal stability and thermal decomposition kinetics of 1-butyl-

5 3-methylimidazolium dicyanamide. Chin. J. Chem. Eng. 18 (2010) 736-741. doi:10.1016/S1004$69541(09) 60122-1$.

7 [122] G.J.T. Fernandes, A.S. Araújo, V.J. Fernandes, C. Novak, Model-free kinetics applied to 8 regeneration of coked alumina, J. Therm. Anal. Calorim. 75 (2004) 687-692. 9 doi:10.1023/B:JTAN.0000027163.44593.4a 